\title{
Simulation of the metabolism of absorbed energy-yielding nutrients in young sheep
}

\author{
By MARGARET GILL', J. H. M. THORNLEY', J. L. BLACK ${ }^{2}$, \\ J. D. OLDHAM ${ }^{3 *}$ AND D. E. BEEVER ${ }^{1}$ \\ ${ }^{1}$ Grassland Research Institute, Hurley, Maidenhead, Berks SL6 5LR \\ ${ }^{2}$ CSIRO, Division of Animal Physiology, Ian Clunies Ross Animal Research Laboratory, \\ Prospect, PO Box 239, Blacktown, New South Wales 2148, Australia \\ ${ }^{3}$ National Institute for Research in Dairying, Shinfield, Reading, Berks RG2 9AT
}

(Received 20 October 1983 - Accepted 3 July 1984)

1. A mathematical model is described, which simulates the metabolism of absorbed nutrients (amino acids, acetic acid, butyric acid, glucose, lipid and propionic acid) in growing sheep.

2. The basic assumption of the model is that each nutrient is partitioned between synthetic, oxidative or intermediate reactions with rates of reaction which are described using enzyme kinetics. These rates depend on the relationship between maximum reaction rates, constants of affinity and inhibition and the concentrations of metabolites as determined by the model.

3. Synthetic reactions calculate fat and protein deposition while intermediate reactions involve the production of ATP and NADPH. There is a total of twelve state variables and the model, programmed in CSMP and ACSL, is solved by integration of twelve differential equations.

4. The model calculates the efficiency of utilization of metabolizable energy for different nutrient inputs and the results may be interpreted in terms of fluxes through the metabolite pools. Simulations using inputs representing forage- and concentrate-based diets indicated decreased efficiency for the forage at high levels of intake and possible reasons for this were further studied in simulations where the inputs of protein and glucose were varied.

The efficiency with which absorbed nutrients are used for fat synthesis is an important factor in determining the feed requirements of ruminants. An increasing metabolizability of the diet (i.e. the proportion of gross energy which is actually metabolized) has been shown to increase the efficiency with which metabolizable energy (ME) is used for growth and fattening $\left(k_{f}\right)$ (Blaxter, 1969). However, the parameters required to describe this relationship differ between feeds. The ME system proposed by the Agricultural Research Council (1980) includes equations for five different classes of feed, but still does not take account of many reported differences, e.g. between spring and autumn grass (Lonsdale \& Tayler, 1971) or between clover and ryegrass (Ulyatt, 1970).

Various hypotheses have been proposed to explain the differences in efficiency and particular attention has been given to changes in the availability of individual nutrients. Blaxter (1962) implicated inefficient utilization of acetate on high-fibre diets to explain the negative relationship between efficiency and crude fibre content (Breirem, 1944). The infusion experiments of Armstrong \& Blaxter (1957) and Armstrong et al. (1958) had shown a lower efficiency of energy retention in response to intra-ruminal infusion of acetate, compared with infusion of propionic and butyric acids. However, the work of Rook et al. (1963) and Ørskov \& Allen (1966) provided contradictory results, in that supplemental acetate was utilized with a similar efficiency to supplemental propionate. In attempting to reconcile this apparent discrepancy, MacRae \& Lobley (1982) pointed out the need to consider the glucogenic potential of the basal diet when predicting the efficiency with which acetate would be used. In particular, they discussed the need to consider amino acid supply

\footnotetext{
* Present address: East of Scotland College of Agriculture, Animal Production Advisory and Development Department, Bush Estate, Ne Penicuik, Midlothian.
} 
to the tissues as a factor modifying the efficiency of acetate use on high-forage diets. Walker $\&$ Norton (1971) reported evidence from milk-fed lambs that the supply of amino acids can influence the efficiency of utilization of absorbed energy-yielding nutrients.

The present paper describes a mathematical model which simulates the metabolism of absorbed nutrients in growing sheep. The principal objective is to evaluate current concepts and data as providing an explanatory basis for dynamic aspects of metabolism, including relationships between absorbed nutrient inputs, growth efficiency and body composition, and also to examine hypotheses in this area that have been proposed. A simplified biochemical representation is chosen as an appropriate vehicle for this objective, and the equations within the model are based on enzyme kinetics and the stoichiometry of the biochemical pathways involved. The present model emphasizes the role of $\mathrm{C}_{3}$ and $\mathrm{C}_{6}$ nutrients and therefore propionate and glucose metabolism are represented in more detail than other metabolites such as butyrate. All models are approximations, and it can always be disputed whether the assumptions and simplifications made are reasonable. The paper is presented in four sections: a mathematical description of the model, details of the parameters used and how they were set, results from a series of simulations with changing nutrient inputs, and a final discussion on the accuracy of both observed and simulated predictions of efficiency of ME utilization.

\section{THE MODEL}

\section{Overall structure and notation}

The scheme assumed is given in Fig. 1; it is a compartmental model with pools and fluxes between the pools; only the principal fluxes are shown in Fig. 1. Two-letter abbreviations are used to define the quantities in the model. These are given in Table 1. In Table 2, variables and parameters are given which describe properties of the model and which are subscripted with the symbols from Table 1 . For example, $C_{\mathrm{Ac}}$ is the concentration of acetic acid, $K_{\mathrm{AaGu}}$ is a Michaelis-Menten constant for the amino acid to glucose reaction, $R_{\mathrm{FaTg}}$, At is the requirement of the fatty acid to triglyceride reaction for ATP. In Table 3, the principal transactions occurring in the model are listed, with reaction sites, principal and auxiliary substrates, inhibitors, and parameters required to specify the rate equations.

SI units are used throughout, with the exception of the SI units for concentration and amount of substance, which are inconsistent with the rest of the SI system. $\mathrm{kg}$ is used for mass, $\mathrm{m}$ for length, time is measured in days, amount of substance is measured in $\mathrm{kg} \mathrm{mol}$ ( $1 \mathrm{~kg} \mathrm{~mol}{ }^{12} \mathrm{C}$ is $12 \mathrm{~kg}^{12} \mathrm{C}$ ), and concentration in $\mathrm{kg} \mathrm{mol} / \mathrm{m}^{3}$, which is identical to the familiar $\mathrm{g} \mathrm{mol} / \mathrm{l}$.

\section{General reaction kinetics}

Reaction rates are described using standard expressions from enzyme kinetics. The utilization rate $U$ of substrate $s$ is

$$
U=V \frac{s}{K+s}=V(1+K / s)^{-1},
$$

where $V$ is the maximum velocity and $K$ is the Michaelis-Menten constant. For two substrates $s_{1}$ and $s_{2}$

$$
U=V\left(1+K_{1} / s_{1}+K_{2} / s_{2}\right)^{-1}
$$

with an obvious extension to three or more substrates. Equation $1 b$ is preferred to the alternative form

$$
U=V\left(1+K_{1} / s_{1}\right)^{-1}\left(1+K_{2} / s_{2}\right)^{-1},
$$

which weights the limitation produced by each substrate independently, and applies to substrates which can react in random order. Equation $1 b$ applies to ordered (and the so-called 'ping-pong') reaction mechanisms (Mahler \& Cordes, 1971). For example, with 


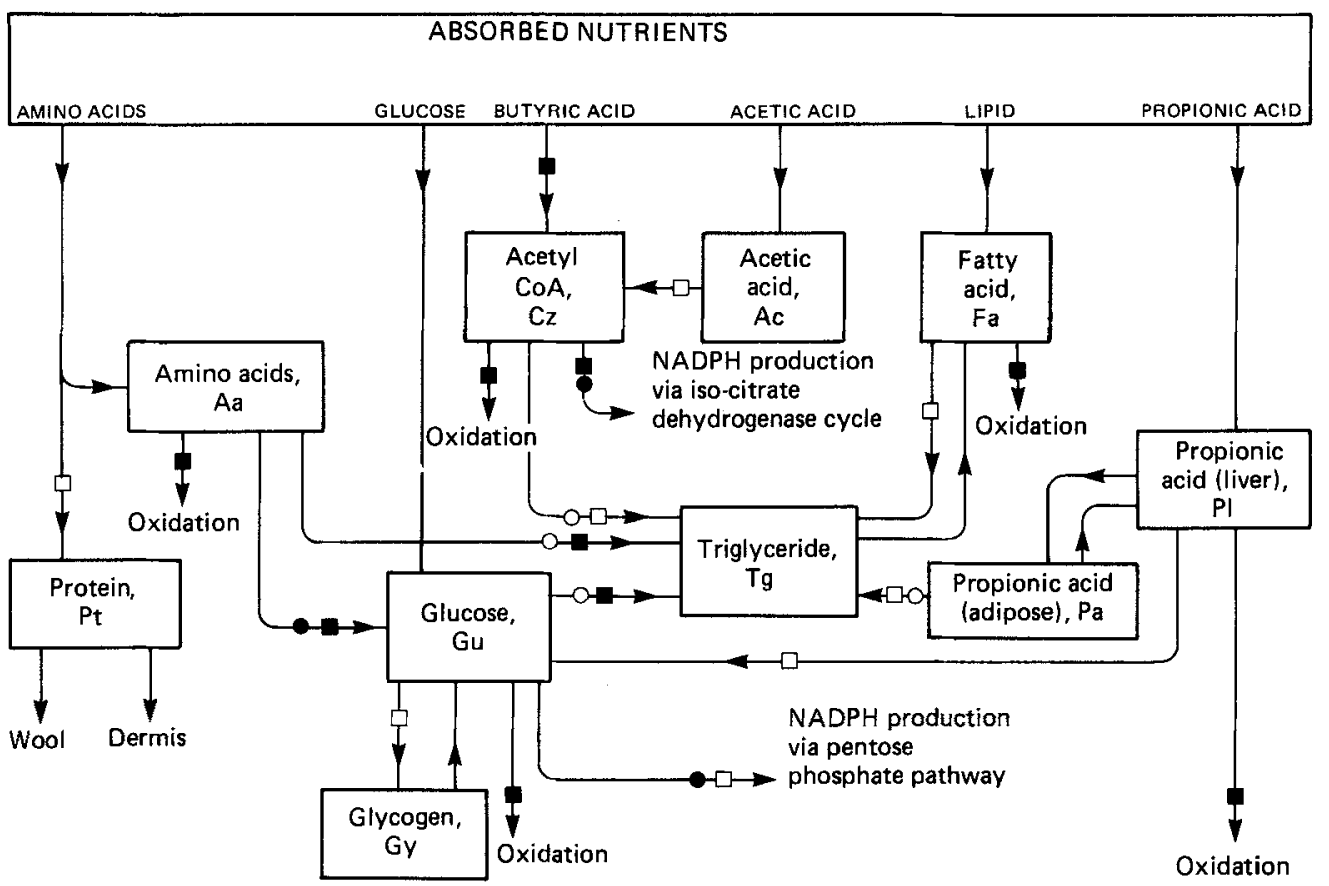

Fig. 1. Model for the efficiency of utilization of absorbed energy. Only the principal substrates and products are shown; carbon dioxide $(\mathrm{Cx})$, oxygen $(\mathrm{Ox})$ and urea (Ur) are also involved in many of these reactions. ATP (At) and NADPH $(\mathrm{Np})$ are two important variables not shown above. The reactions are coded: ( $\square$ ), At-producing; ( $\square$ ), At-requiring; (O), Np-producing; (O) Np-requiring. Maintenance is not shown above, but is a drain on the At pool.

Table 1. Symbols for abbreviations used in the model

\begin{tabular}{cclc}
\hline \hline Substance, process & Symbol & Substance, process & Symbol \\
\hline Acetic acid & $\mathrm{Ac}$ & Glycogen & $\mathrm{Gy}$ \\
Acetyl CoA & $\mathrm{Cz}$ & Lipid & $\mathrm{Lp}$ \\
Amino acids & $\mathrm{Aa}$ & Maintenance & $\mathrm{Ma}$ \\
ATP & $\mathrm{At}$ & NADPH & $\mathrm{Np}$ \\
Butyric acid & $\mathrm{Bu}$ & Oxygen & $\mathrm{Ox}$ \\
Carbon dioxide & $\mathrm{Cx}$ & Propionic acid in: & \\
Degradation & $\mathrm{Dg}$ & Adipose tissue & $\mathrm{Pa}$ \\
Fatty acids & $\mathrm{Fa}$ & Liver & $\mathrm{Pl}$ \\
Glucose & $\mathrm{Gu}$ & Protein & $\mathrm{Pt}$ \\
& & Triglycerides & $\mathrm{Tg}$ \\
& & Urea & $\mathrm{Ur}$ \\
\hline \hline
\end{tabular}

$s_{1}=K_{1}$ and $s_{2}=K_{2}$, equation $1 c$ occurs at 0.25 of $V$ whereas equation $1 b$ gives 0.33 of $V$. With equation $1 b$, the substrate that is least limiting produces a much smaller effect on the reaction velocity than with equation $1 c$.

Inhibition by an inhibitor $i$ is modelled using a multiplicative factor of

$$
(1+i /)^{-1}
$$

where $J$ is an inhibition constant.

Equations $1 a$ and $1 b$ respond linearly to substrate at low substrate concentrations, and successive increments in substrate concentration give successively smaller increases in 
Table 2. General notation used in model; subscripts take values from Table 1

\begin{tabular}{|c|c|c|}
\hline$A_{i}$ & Absorption rate of $i$ & $\mathrm{~kg} \mathrm{~mol} i / \mathrm{d}$ \\
\hline$C_{i}$ & Concentration of $i$ & $\mathrm{~kg} \mathrm{~mol} / \mathrm{m}^{3}$ \\
\hline$E_{i}$ & Energy content of $i$ & $\mathrm{MJ} / \mathrm{kg}$ \\
\hline$J_{i j}$ & Inhibition constant of $i j$ reaction with respect to $j$ & $\mathrm{~kg} \mathrm{~mol} / \mathrm{m}^{3}$ \\
\hline$J_{i j, k}$ & Inhibition constant of $i j$ reaction with respect to $k$ & $\mathrm{~kg} \mathrm{~mol} / \mathrm{m}^{3}$ \\
\hline$K_{i j}$ & $\begin{array}{l}\text { Michaelis-Menten constant of } i j \text { reaction } \\
\text { with respect to } i\end{array}$ & $\mathrm{~kg} \mathrm{~mol} / \mathrm{m}^{3}$ \\
\hline$K_{i j, k}$ & Constant of $i j$ reaction with respect to $k$ & $\mathrm{~kg} \mathrm{~mol} / \mathrm{m}^{3}$ \\
\hline$M_{i j}, M_{i j, k}$ & Sigmoidicity constants for $i j$ reaction & \\
\hline & Rate of production of $i$ & $\operatorname{kg~mol} i / \mathrm{d}$ \\
\hline & Rate of production of $j$ by $i j$ reaction & $\mathrm{kg} \mathrm{mol} j / \mathrm{d}$ \\
\hline$P_{i j, k}$ & Rate of production of $k$ by $i j$ reaction & $\mathrm{kg} \mathrm{mol} k / \mathrm{d}$ \\
\hline$Q_{i}$ & Quantity of $i$ & $\mathrm{~kg} \mathrm{~mol} i$ \\
\hline$R_{i j, k}$ & Requirement of $i j$ reaction for $k$ & $\begin{array}{l}\mathrm{kg} \mathrm{mol} k / \mathrm{kg} \mathrm{mol} \\
i \text { utilized in } i j \text { reaction }\end{array}$ \\
\hline$(R M M)_{i}$ & Relative molecular mass of $i$ & \\
\hline$U_{i j}$ & Rate of utilization of $i$ by $i j$ reaction & $\mathrm{kg} \mathrm{mol} i / \mathrm{d}$ \\
\hline$U_{i j, k}$ & Rate of utilization of $k$ by $i j$ reaction & $\mathrm{kg} \mathrm{mol} k / \mathrm{d}$ \\
\hline$V_{i j}^{j, w}$ & Maximum velocity of $i j$ reaction & $\begin{array}{l}\mathrm{kg} \mathrm{mol} i \text { utilized in } i j \\
\text { reaction/d per } \mathrm{kg} \text { fresh tissue }\end{array}$ \\
\hline$Y_{i j}$ & Yield of $j$ from $i j$ reaction & $\begin{array}{l}\mathrm{kg} \mathrm{mol} \mathrm{j} / \mathrm{kg} \mathrm{mol} i \\
\text { utilized in } i j \text { reaction }\end{array}$ \\
\hline$Y_{i j, k}$ & Yield of $k$ from $i j$ reaction & $\begin{array}{l}\mathrm{kg} \mathrm{mol} k / \mathrm{kg} \mathrm{mol} i \\
\text { utilized in } i j \text { reaction }\end{array}$ \\
\hline
\end{tabular}

rate; there is no point of inflexion. For some reactions, e.g. glucose to triglyceride, at normal glucose levels, the reaction should not proceed at an appreciable rate, whereas at above normal levels of glucose, the reaction should be very active. For these reactions, sigmoidal response equations are required, which give a 'switch-on' characteristic (Thornley, 1976, pp. 48-50). Positive sigmoidal responses are described here by

$$
\left[1+(K / s)^{q}\right]^{-1},
$$

where $q$ is a constant. $q=1$ gives the familiar Michaelis-Menten equation $1 a ; q=2$ gives a weak sigmoidal response, and higher values of $q(2,4,8$, etc. $)$ give progressively sharper 'switch-on' characteristics. Sigmoidal inhibition ('switch-off') responses are similarly modelled with

$$
\left[1+(i / J)^{q}\right]^{-1} .
$$

In equations $1 e$ and $1 f$, the quantity in square brackets varies between 0 and 1 , and 1 and 0 , it is 0.5 at $s=K$ or $i=J$, and the sharpness of the 'switch' depends on the magnitude of $q$.

\section{Weights and volumes}

The maximum reaction velocities ( $V$; Tables 2 and 3 ) are all defined with respect to fresh tissue weight. The weights of components of the animal (see Table 4) are given by

$$
W_{\text {adip }}=890 Q_{\mathrm{Tg}} \text {, }
$$

where 890 is the relative molecular mass $(R M M)$ of glycerol tristearate;

$$
W_{\text {body }}=W_{\text {adip }}+W_{\text {mus }}+7 \cdot 08 \text {, }
$$

where the muscle weight $\left(W_{\text {mus }}\right)$ is obtained from equation 6 , and it is assumed that the weight of the remaining components, which are neither adipose tissue nor muscle, is $7.08 \mathrm{~kg}$;

$$
W_{\text {live }}=W_{\text {body }} / 0 \cdot 86 \text {, }
$$


Table 3. Transactions occurring within the model*

\begin{tabular}{|c|c|c|c|c|c|}
\hline \multirow[b]{2}{*}{ Transaction } & \multirow[b]{2}{*}{ Site } & \multicolumn{2}{|c|}{ Substrates $\nmid$} & \multirow[b]{2}{*}{ Inhibitors } & \multirow[b]{2}{*}{ Parameters } \\
\hline & & Principal & Auxiliary & & \\
\hline $\mathrm{AaCx}$ & Whole body & Aa & - & At & $V_{\mathrm{AaCx}}, K_{\mathrm{AaCx}}, J_{\mathrm{AaCx}}$ \\
\hline $\mathrm{AaGu}$ & Liver & Aa & - & Gu & $V_{\mathrm{AaGu}}, K_{\mathrm{AaGu}}, J_{\mathrm{AaGu}}$ \\
\hline $\mathrm{AaPt}$ & Empirical equation & & & & \\
\hline $\mathrm{AaTg}$ & Adipose + liver & Aa & $\mathrm{Gu}, \mathrm{Np}$ & - & $V_{\mathrm{AaTg}}, K_{\mathrm{AaTg}}, K_{\mathrm{AaTg}, \mathrm{Gu}}, K_{\mathrm{AaTg}, \mathrm{Np}}$ \\
\hline $\mathrm{AcCz}$ & Whole-body & Ac & & & $V_{\mathrm{AcCz}}, K_{\mathrm{AcCz}}, K_{\mathrm{AcCz}, \mathrm{At}}$ \\
\hline AtDg & Whole-body & At & - & & $V_{\mathrm{AtDg}}, K_{\mathrm{AtDg}}, M_{\mathrm{AtDg}}$ \\
\hline AtMa & Empirical equation & & & & \\
\hline $\mathrm{CzCx}$ & Whole body & $\mathrm{Cz}$ & - & At & $V_{\mathrm{CzCx}}, K_{\mathrm{CzCx}}, J_{\mathrm{CzCx}}$ \\
\hline $\mathrm{CzNp}$ & Adipose + liver & $\mathrm{Cz}$ & - & At, $\mathrm{Np}$ & $V_{\mathrm{CzNp}}, K_{\mathrm{CzNp}}, J_{\mathrm{CzNp}}, J_{\mathrm{CzNp}, \mathrm{At}}$ \\
\hline $\mathrm{CzTg}$ & Adipose + liver & $\mathrm{Cz}$ & At, $\mathrm{Gu}, \mathrm{Np}$ & & $\begin{array}{l}V_{\mathrm{CzTg}}, K_{\mathrm{CzTg}}, K_{\mathrm{CzTg}, \mathrm{At}}, K_{\mathrm{CzTg}, \mathrm{Gu}} \\
K_{\mathrm{CzTg}, \mathrm{Np}}\end{array}$ \\
\hline $\mathrm{FaCx}$ & Whole-body & $\mathrm{Fa}$ & - & At & $V_{\mathrm{FaCx}}, K_{\mathrm{FaCx}}, J_{\mathrm{FaCx}}$ \\
\hline FaTg & Adipose + liver & $\mathrm{Fa}$ & $\mathrm{At}, \mathrm{Gu}$ & - & $V_{\mathrm{FaTg}}, K_{\mathrm{FaTg}}, K_{\mathrm{FaTg}, \mathrm{At}}, K_{\mathrm{FaTg}, \mathrm{Gu}}$ \\
\hline $\mathrm{GuCx}$ & Whole-body & $\mathrm{Gu}$ & - & At & $V_{\mathrm{GuCx}}, K_{\mathrm{GuCx}}, J_{\mathrm{GuCx}}$ \\
\hline GuGy & Liver + muscle & $\mathrm{Gu}$ & At & Gy & $V_{\mathrm{GuGy}}, K_{\mathrm{GuGy}}, K_{\mathrm{GuGy}, \mathrm{At}}, Q_{\mathrm{Gy}, \max }$ \\
\hline GuNp & Adipose + liver & $\mathrm{Gu}$ & At & $\mathrm{Np}$ & $V_{\mathrm{GuNp}}, K_{\mathrm{GuNp}}, K_{\mathrm{GuNp}, \mathrm{At}}, J_{\mathrm{GuNp}}$ \\
\hline GuTg & Adipose + liver & $\mathrm{Gu} \ddagger$ & $\mathrm{Np}$ & - & $\begin{array}{l}V_{\text {GuTg }}, K_{\mathrm{GuTg}}, M_{\mathrm{GuTg}} \\
K_{\mathrm{GuTg}, \mathrm{Np}}\end{array}$ \\
\hline GyGu & Liver + muscle & Gy & - & Guł & $\begin{array}{l}V_{\mathrm{GyGu}}, K_{\mathrm{GyGu}}, M_{\mathrm{GyGu}}, J_{\mathrm{GyGu}, \mathrm{Gu}}, \\
M_{G \mathrm{GGu}, \mathrm{Gu}}\end{array}$ \\
\hline $\mathrm{PaP1}$ & Transport in blood & $\mathrm{Pa}$ & $\bar{a}$ & - & $v_{\text {bfr }}$ \\
\hline PaTg & Adipose & $\mathbf{P a}$ & At, $\mathrm{Gu}, \mathrm{Np}$ & - & $\begin{array}{l}V_{\mathrm{PaTg}}, K_{\mathrm{PaTg}}, K_{\mathrm{PaTg}, \mathrm{At}}, K_{\mathrm{PaTg}, \mathrm{Gu}} \\
K_{\mathrm{PaTg}, \mathrm{Np}}\end{array}$ \\
\hline PICx & Liver & PI & - & At & $V_{\mathrm{PlCx}}, K_{\mathrm{PlCx}}, J_{\mathrm{PlCx}}$ \\
\hline PIGu & Liver & Pl & At & Gu & $V_{\mathrm{PlGu}}, K_{\mathrm{PlGu}}, K_{\mathrm{PlGu}, \mathrm{At}}, J_{\mathrm{PlGu}}$ \\
\hline $\mathrm{PIPa}$ & Transport in blood & PI & - & - & see PaPl \\
\hline $\mathrm{TgFa}$ & Adipose & $\operatorname{Tg} \ddagger$ & - & At & $\begin{array}{l}V_{\mathrm{TgFa}}, K_{\mathrm{TgFa}}, M_{\mathrm{TgFa}}, J_{\mathrm{TgFa}, \mathrm{At}}, \\
M_{\mathrm{TgFa}, \mathrm{At}}\end{array}$ \\
\hline
\end{tabular}

* See Tables 1,2 and 4 for explanation of notations.

$\dagger$ Non-limiting substrates such as oxygen and carbon dioxide are ignored.

$\ddagger$ Denotes a sigmoidal response.

(M. J. Gibb, personal communication);

$$
W_{\text {liver }}=0.0396 W_{\text {body }}^{0.78} \text {, }
$$

from Baldwin \& Black (1979, Table 1);

and

$$
\begin{aligned}
& W_{\text {met }}=W_{\text {body }}{ }^{0.75} ; \\
& W_{\text {mus }}=3.9 \times 110 \times Q_{\mathrm{Pt}},
\end{aligned}
$$

from Murray \& Slezacek (1976).

The blood volume $\left(v_{\mathrm{bld}}\right)$ is assumed to be given by

$$
v_{\text {bld }}=0.0000441 W_{\text {body }}{ }^{1 \cdot 07} \text {, }
$$

from Baldwin \& Black (1979, Table 1). The volume flow rate of blood ( $v_{\text {brr }}$ ), which transports propionate between the liver and adipose tissue, is assumed to be proportional to body-weight, although this assumption is unimportant for the time period of $2 \mathrm{~d}$ examined using the model, during which body-weight scarcely changes. The constant of proportionality is calculated from Pethick et al. (1981, p. 104), giving

$$
v_{\text {ber }}=0.0547 W_{\text {body }} \text {. }
$$


Table 4. Definitions of specific symbols and assumed or initial values

\begin{tabular}{|c|c|c|}
\hline $\begin{array}{l}B_{V} \\
E_{\text {abs }} \\
E_{\text {dig }} \\
E_{\text {ferm }} \\
E_{\text {Ma }} \\
E_{\text {Met }} \\
E_{\text {ret }} \\
R_{Q} \\
v_{\text {addp }} \\
v_{\text {hir }} \\
v_{\text {bid }} \\
v_{\text {liver }} \\
W_{\text {adip }} \\
W_{\text {body }} \\
W_{\text {liver }} \\
W_{\text {live }} \\
W_{\text {met }} \\
W_{\text {mus }}\end{array}$ & $\begin{array}{l}\text { Biological value }(0.75) \\
\text { Absorbed energy } \\
\text { Digestible energy } \\
\text { Heat of fermentation } \\
\text { Energy required for maintenance } \\
\text { Metabolizable energy intake } \\
\text { Retained energy } \\
\text { Respiratory quotient } \\
\text { Volume of adipose tissue }\left(4 \cdot 27 \times 10^{-3}\right) \\
\text { Volume flow rate of blood }(1 \cdot 37) \\
\text { Volume of blood }\left(1.38 \times 10^{-3}\right) \\
\text { Volume of liver }\left(0.488 \times 10^{-3}\right) \\
\text { Weight of adipose tissue }(4 \cdot 27) \\
\text { Empty body-weight }(25) \\
\text { Weight of liver }(0 \cdot 488) \\
\text { Live weight of animal } \\
\text { Metabolic weight of animal }(11 \cdot 18) \\
\text { Weight of muscle }(13.65)\end{array}$ & $\begin{array}{l}\mathrm{MJ} / \mathrm{d} \\
\mathrm{MJ} / \mathrm{d} \\
\mathrm{MJ} / \mathrm{d} \\
\mathrm{MJ} / \mathrm{d} \\
\mathrm{MJ} / \mathrm{d} \\
\mathrm{MJ} / \mathrm{d} \\
\mathrm{mol} \text { carbon dioxide/mol oxygen } \\
\mathrm{m}^{3} \\
\mathrm{~m}^{3} / \mathrm{d} \\
\mathrm{m}^{3} \\
\mathrm{~m}^{3} \\
\mathrm{~kg}^{3} \\
\mathrm{~kg} \\
\mathrm{~kg} \\
\mathrm{~kg} \\
\mathrm{~kg} \\
\mathrm{~kg}\end{array}$ \\
\hline
\end{tabular}

The volumes of adipose tissue and liver are assumed to be given by

$$
v_{\text {adip }}=W_{\text {adip }} / 1000 \text { and } v_{\text {liver }}=W_{\text {liver }} / 1000 \text {. }
$$

\section{Nutritional inputs}

Numerical values are ascribed to the six nutrient fluxes $\left(A_{\mathrm{Aa}}, A_{\mathrm{Gu}}, A_{\mathrm{Bu}}, A_{\mathrm{Ac}}, A_{\mathrm{Lp}}, A_{\mathrm{Pl}}\right)$ which are actually absorbed by the animal (see Fig. 1). These inputs were held constant during each run of the computer program and did not change with the progress of time, as they would in a fully dynamic model.

Using the definitions in Tables 2 and 4 , the absorbed energy $\left(E_{\mathrm{abs}}\right)$ is obtained by

$$
E_{\mathrm{abs}}=\sum_{i} E_{i} A_{i}(R M M)_{i}
$$

The ME intake $\left(E_{\text {met }}\right)$ is defined by

$$
E_{\mathrm{met}}=E_{\mathrm{abs}}+E_{\mathrm{ferm}}-E_{\mathrm{Ur}},
$$

where the heat of fermentation ( $E_{\text {ferm }}$ ) is obtained from (Webster et al. 1975)

$$
E_{\text {ferm }}=0.06 E_{\text {abs, }}
$$

and the urine energy $\left(E_{\mathrm{ur}}\right)$ is calculated within the model. Finally, the digestible energy $\left(E_{\mathrm{dig}}\right)$ is obtained from

$$
E_{\text {dig }}=E_{\text {met }} / 0 \cdot 81 \text {, }
$$

from Ministry of Agriculture, Fisheries and Food (1975, p. 3, equation 1).

\section{Concentrations}

With the exception of propionate, all the concentrations $C_{i}$ are obtained from the volume of blood ( $\left.v_{\mathrm{bld}}\right)$ and the quantity $Q_{i}$ by means of

$$
C_{i}=Q_{i} / v_{\mathrm{bld}}
$$


For example, for acetic acid

$$
C_{\mathrm{Ac}}=Q_{\mathrm{Ac}} / v_{\text {bld }} .
$$

The propionic acid concentrations in adipose and liver are obtained by

$$
C_{\mathrm{Pa}}=Q_{\mathrm{Pa}} / v_{\text {adip }} \text { and } C_{\mathrm{P} 1}=Q_{\mathrm{P} 1} / v_{\text {liver }}
$$

State variables and pools

The model has twelve state variables (the quantities $\mathrm{Aa}, \mathrm{Ac}, \mathrm{At}, \mathrm{Cz}, \mathrm{Fa}, \mathrm{Gu}, \mathrm{Gy}, \mathrm{Np}, \mathrm{Pa}$, $\mathrm{Pl}, \mathrm{Pt}$ and $\mathrm{Tg}$ ) each of which is a representation of a metabolic pool. The description of these pools is similar in each case. Inputs and outputs are described separately. The rate of change of mass in the pool is then given by a differential equation which describes the difference between input and output rates:

$$
\frac{d(\text { pool })}{d t}=\text { inputs }- \text { outputs. }
$$

The pools, together with carbon dioxide and oxygen relations, maintenance, and urea production, are described in alphabetical order.

\section{Acetic acid pool, Ac}

Inputs. The only input to the pool is the absorbed nutrient input $A_{\mathrm{Ac}}$.

Outputs. There is just the one reaction, with a flux of (Table 3)

$$
U_{\mathrm{AcCz}}=W_{\mathrm{body}} V_{\mathrm{AcCz}}\left(1+K_{\mathrm{AcCz}} / C_{\mathrm{Ac}}+K_{\mathrm{AcCz}, \mathrm{At}} / C_{\mathrm{At}}\right)^{-1} \text {. }
$$

Differential equation. Summing the terms, the rate of change of the quantity of acetic acid $\left(Q_{\mathrm{Ac}}\right)$ is given by

$$
\frac{d Q_{\mathrm{Ac}}}{d t}=A_{\mathrm{Ac}}-U_{\mathrm{AcCz}} .
$$

\section{Acetyl CoA pool, $\mathrm{Cz}$}

Inputs. $\mathrm{Cz}$ is produced at the rate $P_{\mathrm{AcCz}}$ from acetic acid (Ac), given by

$$
P_{\mathrm{AcCz}}=Y_{\mathrm{AcCz}} U_{\mathrm{AcCz}}
$$

where $U_{\mathrm{AcCz}}$ is defined by equation 12 . There is a second input as it is assumed that the nutrient input of butyric acid $\left(A_{\mathrm{Bu}}\right)$ is converted immediately into $\mathrm{Cz}$; this is written

$$
P_{\mathrm{BuCz}}=Y_{\mathrm{BuCz}} A_{\mathrm{Bu}} \text {. }
$$

Outputs. There are three outputs (Fig. 1): from Table 3 these are

$$
\begin{aligned}
& U_{\mathrm{CzCx}}= W_{\mathrm{body}} V_{\mathrm{CzCx}}\left(1+K_{\mathrm{CzCx}} / C_{\mathrm{Cz}}\right)^{-1}\left(1+C_{\mathrm{At}} / J_{\mathrm{CzCx}}\right)^{-1} \\
& U_{\mathrm{CzNp}}=\left(W_{\mathrm{adip}}+W_{\text {liver }}\right) V_{\mathrm{CzNp}}\left(1+K_{\mathrm{CzNp}} / C_{\mathrm{Cz}}\right)^{-1} \\
& \quad \times\left(1+C_{\mathrm{Np}} / J_{\mathrm{CzNp}}\right)^{-1}\left(1+C_{\mathrm{At}} / J_{\mathrm{CzNp}, \mathrm{At}}\right)^{-1} \\
& U_{\mathrm{CzTg}}=\left(W_{\mathrm{adip}}+W_{\mathrm{liver}}\right) V_{\mathrm{CzTg}}\left(1+K_{\mathrm{CzTg}} / C_{\mathrm{Cz}}+K_{\mathrm{CzTg}, \mathrm{At}} / C_{\mathrm{At}}\right. \\
&+ \\
&\left.+K_{\mathrm{CzTg}, \mathrm{Gu}} / C_{\mathrm{Gu}}+K_{\mathrm{CzTg}, \mathrm{Np}} / C_{\mathrm{Np}}\right)^{-1}
\end{aligned}
$$

In all fat synthesis reactions ( $\mathrm{AaTg}, \mathrm{CzTg}, \mathrm{PaTg}$ and $\mathrm{GuTg}$ ) the substrate is assumed to be completely metabolized to tristearin without passing through the fatty acid pool. This avoided double-accounting of ATP utilization through both maintenance requirement and futile cycling between acetyl CoA and fatty acids. 
Differential equation. Summing the terms, this is

$$
\frac{d Q_{\mathrm{Cz}}}{d t}=P_{\mathrm{AcCz}}+P_{\mathrm{BuCz}}-U_{\mathrm{CzCx}}-U_{\mathrm{CzNp}}-U_{\mathrm{CzTg}} .
$$

Amino acid pool, $\mathrm{Aa}$

Inputs. The only inputs to this catabolic pool are derived from the absorbed nutrient input $A_{\mathrm{Aa}}$. This is assigned a biological value $\left(B_{V}\right)$ so that amino acids which are in excess of the limiting amino acid for protein synthesis, described by

$$
\left(1-B_{V}\right) A_{\mathrm{Aa}} \text {, }
$$

are input to the amino acid pool. $P_{\mathrm{Pt} \text {, max }}$ is defined as the maximum possible rate of protein accretion at a particular body-weight and energy intake (equation 50). $P_{\mathrm{Pt}, \text { max }}$ includes the synthesis of wool and dermis. Since the maximum rate of protein accretion allowed by diet input is $B_{V} A_{\mathrm{Aa}}$, then the actual rate of protein accretion $P_{\mathrm{AaPt}}$ is the smaller of $P_{\mathrm{Pt}, \max }$ and the dietary limit $B_{V} A_{\mathrm{Aa}}$, which is denoted by

$$
U_{\mathrm{AaPt}}=P_{\mathrm{AaPt}}=\operatorname{minimum}\left(P_{\mathrm{Pt}, \max }, B_{V} A_{\mathrm{Aa}}\right) \text {. }
$$

There is thus a possible second input to the amino acid pool representing amino acids in excess of those of correct $B_{V}$ required for protein deposition, of

$$
B_{V} A_{\mathrm{Aa}}-P_{\mathrm{AaPt}} \text {. }
$$

Outputs. There are three outputs from the amino acid pool (Fig. 1 and Table 3):

$$
\begin{aligned}
U_{\mathrm{AaCx}}= & W_{\mathrm{body}} V_{\mathrm{AaCx}}\left(1+K_{\mathrm{AaCx}} / C_{\mathrm{Aa}}\right)^{-1}\left(1+C_{\mathrm{At}} / J_{\mathrm{AaCx}}\right)^{-1} ; \\
U_{\mathrm{AaGu}}= & W_{1 \mathrm{iver}} V_{\mathrm{AaGu}}\left(1+K_{\mathrm{AaGu}} / C_{\mathrm{Aa}}\right)^{-1}\left(1+C_{\mathrm{Gu}} / J_{\mathrm{AaGu}}\right)^{-1} ; \\
U_{\mathrm{AaTg}}= & \left(W_{\mathrm{adip}}+W_{\text {liver }}\right) V_{\mathrm{AaTg}}\left(1+K_{\mathrm{AaTg}} / C_{\mathrm{Aa}}\right. \\
& \left.\quad+K_{\mathrm{AaTg}, \mathrm{Gu}} / C_{\mathrm{Gu}}+K_{\mathrm{AaTg}, \mathrm{Np}} / C_{\mathrm{Np}}\right)^{-1} .
\end{aligned}
$$

This last pathway is assumed to occur since amino acids contributing to acetyl CoA or pyruvate production can provide carbon for triglyceride synthesis (Reeds et al. 1982).

Differential equation. From equations 17 and 18, therefore

$$
\frac{d Q_{\mathrm{Aa}}}{d t}=A_{\mathrm{Aa}}-U_{\mathrm{AaPt}}-U_{\mathrm{AaCx}}-U_{\mathrm{AaGu}}-U_{\mathrm{AaTg}} .
$$

\section{ATP pool, $A t$}

Inputs and outputs from this pool arise mainly from stoichiometric descriptions of the ATP required to derive other fluxes in the model, or as yields of ATP as a result of other fluxes.

Inputs.

$$
\begin{array}{ll}
P_{\mathrm{AaCx}, \mathrm{At}}=Y_{\mathrm{AaCx}, \mathrm{At}} U_{\mathrm{AaCx}} ; & P_{\mathrm{AaGu}, \mathrm{At}}=Y_{\mathrm{AaGu}, \mathrm{At}} U_{\mathrm{AaGu}} ; \\
P_{\mathrm{AaTg}, \mathrm{At}}=Y_{\mathrm{AaTg}, \mathrm{At}} U_{\mathrm{AaTg}} ; & P_{\mathrm{BuCz}, \mathrm{At}}=Y_{\mathrm{BuCz}, \mathrm{At}} A_{\mathrm{Bu}} ; \\
P_{\mathrm{CzCx}, \mathrm{At}}=Y_{\mathrm{CzCx}, \mathrm{At}} U_{\mathrm{CzCx}} ; & P_{\mathrm{CzNp}, \mathrm{At}}=Y_{\mathrm{CzNp}, \mathrm{At}} U_{\mathrm{CzNp}} ; \\
P_{\mathrm{FaCx}, \mathrm{At}}=Y_{\mathrm{FaCx}, \mathrm{At}} U_{\mathrm{FaCx}} ; & P_{\mathrm{GuCx}, \mathrm{At}}=Y_{\mathrm{GuCx}, \mathrm{At}} U_{\mathrm{GuCx}} ; \\
P_{\mathrm{GuTg}, \mathrm{At}}=Y_{\mathrm{GuTg}, \mathrm{At}} U_{\mathrm{GuTg}} ; & P_{\mathrm{PlCx}, \mathrm{At}}=Y_{\mathrm{PlCx}, \mathrm{At}} U_{\mathrm{PlCx}} .
\end{array}
$$


Outputs.

$$
\begin{aligned}
& U_{\mathrm{AaPt}, \mathrm{At}}=R_{\mathrm{AaPt}, \mathrm{At}} U_{\mathrm{AaPt}} ; \quad U_{\mathrm{AcCz}, \mathrm{At}}=R_{\mathrm{AcCz}, \mathrm{At}} U_{\mathrm{AcCz}} ; \\
& U_{\mathrm{CzTg}, \mathrm{At}}=R_{\mathrm{CzTg}, \mathrm{At}} U_{\mathrm{CzTg}} ; \quad U_{\mathrm{FaTg}, \mathrm{At}}=R_{\mathrm{FaTg}, \mathrm{At}} U_{\mathrm{FaTg}} ; \\
& U_{\mathrm{GuGy}, \mathrm{At}}=R_{\mathrm{GuGy}, \mathrm{At}} U_{\mathrm{GuGy}} ; \quad U_{\mathrm{GuNp}, \mathrm{At}}=R_{\mathrm{GuNp}, \mathrm{At}} U_{\mathrm{GuNp}} ; \\
& U_{\mathrm{Ma}, A \mathrm{t}} \text { (see maintenance section and equation } 40 \mathrm{~b} \text { ); } \\
& U_{\mathrm{PlGu}, \mathrm{At}}=R_{\mathrm{PlGu}, \mathrm{At}} U_{\mathrm{PlGu}} ; \quad U_{\mathrm{PaTg}, \mathrm{At}}=R_{\mathrm{PaTg}, \mathrm{At}} U_{\mathrm{PaTg}} .
\end{aligned}
$$

There is an additional energy cost associated with nitrogen excretion in urea (Ur); it is assumed that this cost is met from the ATP pool, according to

$$
U_{\mathrm{Ur}, \mathrm{At}}=R_{\mathrm{Ur}, \mathrm{At}} \frac{d Q_{\mathrm{Ur}}}{d t} .
$$

In some early runs of the model, it was found that the ATP pool would sometimes increase without limit. This arises because some futile cycles and other ATP-degrading processes have not been included in the model. It was found necessary to introduce an ATP degrader into the equations to put an upper limit on ATP. This is achieved by means of

$$
U_{\mathrm{AtDg}}=V_{\mathrm{AtDg}}\left[1+\left(K_{\mathrm{AtDG}} / C_{\mathrm{AT}}\right)^{\left.M_{\mathrm{AtDg}}\right]^{-1}}\right. \text {. }
$$

Differential equation.

$$
\frac{d Q_{\mathrm{At}}}{d t}=\text { inputs }- \text { outputs }
$$

Carbon dioxide $(C \dot{x})$, Oxygen $(O x)$ and respiratory quotient $\left(\mathrm{R}_{\mathbf{Q}}\right)$ Carbon dioxide production.

$$
\begin{array}{ll}
P_{\mathrm{AaCx}}=Y_{\mathrm{AaCx}} U_{\mathrm{AaCx}} ; & P_{\mathrm{AaGu}, \mathrm{Cx}}=Y_{\mathrm{AaGu}, \mathrm{Cx}} U_{\mathrm{AaGu}} ; \\
P_{\mathrm{AaTg}, \mathrm{Cx}}=Y_{\mathrm{AaTg}, \mathrm{cx}} U_{\mathrm{AaTg}} ; & P_{\mathrm{CzCx}}=Y_{\mathrm{CzCx}} U_{\mathrm{CzCx}} ; \\
P_{\mathrm{CzNp}, \mathrm{Cx}}=Y_{\mathrm{CzNp}, \mathrm{Cx}} U_{\mathrm{CzNp}} ; & P_{\mathrm{FaCx}}=Y_{\mathrm{FaCx}} U_{\mathrm{FaCx}} ; \\
P_{\mathrm{GuCx}}=Y_{\mathrm{GuCx}} U_{\mathrm{GuCx}} ; & P_{\mathrm{GuNp}, \mathrm{Cx}}=Y_{\mathrm{GuNp}, \mathrm{Cx}} U_{\mathrm{GuNp}} ; \\
P_{\mathrm{GuTg}, \mathrm{Cx}}=Y_{\mathrm{GuTg}, \mathrm{Cx}} U_{\mathrm{GuTg}} ; & P_{\mathrm{PlCx}}=Y_{\mathrm{PICx}} U_{\mathrm{PlCx}} .
\end{array}
$$

Carbon dioxide requirement.

$$
U_{\mathrm{PaTg}, \mathrm{Cx}}=R_{\mathrm{PaTg}, \mathrm{Cx}} U_{\mathrm{PaTg}} .
$$

Net carbon dioxide production. This is given by

Oxygen requirement.

$$
\frac{d Q_{\mathrm{Cx}}}{d t}=\text { production terms }-U_{\mathrm{PaTg}, \mathrm{Cx}} \text {. }
$$

$$
\begin{aligned}
& U_{\mathrm{AaCx}, O x}=R_{\mathrm{AaCx}, 0 \mathrm{Ox}} U_{\mathrm{AaCx}} ; \quad U_{\mathrm{AaGu}, \mathrm{Ox}}=R_{\mathrm{AaGu}, 0 \mathrm{Ox}} U_{\mathrm{AaGu}} ; \quad(26 a, b) \\
& U_{\mathrm{AaTg}, \mathrm{Ox}}=R_{\mathrm{AaTg}, \mathrm{Ox}} U_{\mathrm{AaTg}} ; \quad U_{\mathrm{CzCx}, \mathrm{Ox}}=R_{\mathrm{CzCx}, \mathrm{Ox},} U_{\mathrm{CzCx}} ; \quad(26 c, d) \\
& U_{\mathrm{CzNp}, O \mathrm{Ox}}=R_{\mathrm{CzNp}, \mathrm{Ox}} U_{\mathrm{CzNp}} ; \quad U_{\mathrm{FaCx}, \mathrm{Ox}}=R_{\mathrm{FaCx}, \mathrm{Ox}} U_{\mathrm{FaCx}} ; \quad(26 e, f) \\
& U_{\mathrm{GuCx}, \text { ox }}=R_{\mathrm{GuCx}, \text { ox }} U_{\mathrm{GuCx}} ; \quad U_{\mathrm{GuTg}, \text { ox }}=R_{\mathrm{GuTg}, \text { ox }} U_{\mathrm{GuTg}} ; \quad(26 g, h) \\
& U_{\mathrm{PICx}, \text { ox }}=R_{\mathrm{PICx}, \text { ox }} U_{\mathrm{PICx}} ; \quad U_{\mathrm{PlGu}, \mathrm{Ox}}=R_{\mathrm{PIGu}, 0 \mathrm{Ox}} U_{\mathrm{PlGu}} . \quad(26 i, j)
\end{aligned}
$$


Net oxygen requirement.

$$
\frac{d Q_{\mathrm{Ox}}}{d t}=\Sigma \text { requirement terms. }
$$

Respiratory quotient $\mathbf{R}_{\mathbf{Q}}$. This is defined by

$$
R_{Q}=\frac{d Q_{\mathrm{Cx}}}{d t} / \frac{d Q_{\mathrm{Ox}}}{d t}
$$

Fatty acid pool, $\mathrm{Fa}$

It is assumed that the synthesis of tristearin from primary substances proceeds to completion without passing through the fatty acid pool, and the only inputs into the Fa pool are from lipid absorption or tristearin breakdown.

Inputs.

Outputs.

$$
P_{\mathrm{LpFa}}=Y_{\mathrm{LpFa}} A_{\mathrm{Lp}} ; \quad P_{\mathrm{TgFa}}=Y_{\mathrm{TgFa}} U_{\mathrm{TgFa}}
$$

$$
\begin{aligned}
& U_{\mathrm{FaCx}}=W_{\mathrm{body}} V_{\mathrm{FaCx}}\left(1+K_{\mathrm{FaCx}} / C_{\mathrm{Fa}}\right)^{-1}\left(1+C_{\mathrm{At}} / J_{\mathrm{FaCx}}\right)^{-1} ; \\
& U_{\mathrm{FaTg}}=\left(W_{\text {adip }}+W_{\mathrm{ilver}}\right) V_{\mathrm{FaTg}}\left(1+K_{\mathrm{FaTg}} / C_{\mathrm{Fa}}+K_{\mathrm{FaTg}, \mathrm{At}} / C_{\mathrm{At}}+K_{\mathrm{FaTg}, \mathrm{Gu}} / C_{\mathrm{Gu}}\right)^{-1} .
\end{aligned}
$$

Differential equation.

$$
\frac{d Q_{\mathrm{Fa}}}{d t}=P_{\mathrm{LpFa}}+P_{\mathrm{TgFa}}-U_{\mathrm{FaCx}}-U_{\mathrm{FaTg}} .
$$

\section{Glucose pool, Gu}

There are two inputs of absorbed nutrients into the glucose pool: from dietary glucose and from the glycerol moiety of the lipid input. Within the model, glucose is synthesized from amino acids and propionate released from glycogen and from glycerol during lipolysis. Glucose in the form of glycerol is required in the five reactions of triglyceride synthesis.

Inputs.

Outputs.

$$
\begin{aligned}
P_{\mathrm{AaGu}}= & Y_{\mathrm{AaGu}} U_{\mathrm{AaGu}} ; \quad P_{\mathrm{GyGu}}=Y_{\mathrm{GyGu}} U_{\mathrm{GyGu}} ; \\
P_{\mathrm{L} p \mathrm{Gu}}= & Y_{\mathrm{LgGu}} A_{\mathrm{Lg}} ; \quad P_{\mathrm{PlGu}}=Y_{\mathrm{P} 1 \mathrm{Gu}} U_{\mathrm{PlGu}} ; \\
& P_{\mathrm{TgFa}, \mathrm{Gu}}=Y_{\mathrm{TgFa}, \mathrm{Gu}} U_{\mathrm{TgFa}} .
\end{aligned}
$$

$$
U_{\mathrm{GuCx}}=W_{\mathrm{body}} V_{\mathrm{GuCx}}\left(1+K_{\mathrm{GuCx}} / C_{\mathrm{Gu}}\right)^{-1}\left(1+C_{\mathrm{At}} / J_{\mathrm{GuCx}}\right)^{-1}
$$

For glycogen synthesis from glucose, it is assumed that not more than a certain quantity of glycogen, $Q_{\mathrm{Gy} \text {, max }}$, can be laid down, and glucose utilization for glycogen synthesis is limited by an extra term, according to

$$
U_{\mathrm{GuGy}}=\left(W_{11 \mathrm{ver}}+W_{\mathrm{mus}}\right) V_{\mathrm{GuGy}}\left(1+K_{\mathrm{GuGy}} / C_{\mathrm{Gu}}+K_{\mathrm{GuGy}, \mathrm{At}} / C_{\mathrm{At}}\right)^{-1}\left(1-Q_{\mathrm{Gy}} / Q_{\mathrm{Gy}, \max }\right) \text {, }
$$

where $Q_{\mathrm{Gy}, \max }$ is obtained from equation 34. It is assumed that glucose oxidized by the pentose-phosphate pathway is completely oxidized to carbon dioxide.

$$
\begin{gathered}
U_{\mathrm{GuNp}}=\left(W_{\mathrm{adip}}+W_{\mathrm{liver}}\right) V_{\mathrm{GuNp}}\left(1+K_{\mathrm{GuNp}} / C_{\mathrm{Gu}}\right. \\
\left.+K_{\mathrm{GuNp}, \mathrm{At}} / C_{\mathrm{At}}\right)^{-1}\left(1+C_{\mathrm{Np}} / J_{\mathrm{GuNp}}\right)^{-1} \\
U_{\mathrm{GuTg}}=\left(W_{\mathrm{adip}}+W_{\text {liver }}\right) V_{\mathrm{GuTg}}\left[1+\left(K_{\mathrm{GuTg}} / C_{\mathrm{Gu}}\right)^{\left.M_{\mathrm{GuTg}}\right]^{-1}}\right. \\
\times\left(1+K_{\mathrm{GuTg}, \mathrm{Np}} / C_{\mathrm{Np}}\right)^{-1}
\end{gathered}
$$




$$
\begin{array}{ll}
U_{\mathrm{AaTg}, \mathrm{Gu}}=R_{\mathrm{AaTg}, \mathrm{Gu}} U_{\mathrm{AaTg}} ; & U_{\mathrm{CzTg}, \mathrm{Gu}}=R_{\mathrm{CzTg}, \mathrm{Gu}} U_{\mathrm{CzTg}} ; \\
U_{\mathrm{FaTg}, \mathrm{Gu}}=R_{\mathrm{FaTg}, \mathrm{Gu}} U_{\mathrm{FaTg}} ; & U_{\mathrm{PaTg}, \mathrm{Gu}}=R_{\mathrm{PaTg}, \mathrm{Gu}} U_{\mathrm{PaTg}} .
\end{array}
$$

The auxiliary equation required to evaluate $Q_{\mathrm{Gy}, \max }$ for equation $33 b$ is

$$
Q_{\mathrm{Gy}, \max }=\left(0.02 W_{\text {mus }}+0.06 W_{\text {liver }}\right) / 180,
$$

where it is assumed that, at most, muscle contains $2 \%$ glycogen (McVeigh \& Tarrant, 1982) and liver $6 \%$ glycogen (Leng \& Annison, 1963).

Differential equation.

$$
\frac{d Q_{\mathrm{Gu}}}{d t}=\text { inputs }- \text { outputs. }
$$

\section{Glycogen pool, Gy}

Glycogen is a storage pool for excess glucose which can be used when needed; it may therefore be more important for infrequent feeding, than with continuous absorption of nutrients as at present.

Input.

Output.

$$
P_{\mathrm{GuGy}}=Y_{\mathrm{GuGy}} U_{\mathrm{GuGy}} .
$$

$$
\begin{aligned}
U_{\mathrm{GyGu}}=\left(W_{1 \mathrm{iver}}+W_{\mathrm{mus}}\right) V_{\mathrm{GyGu}}\left[\left(1+\left(K_{\mathrm{GyGu}} / C_{\mathrm{Gy}}\right)^{\left.M_{\mathrm{GyGu}}\right]^{-1}}\right.\right. & \times\left[\left(1+\left(C_{\mathrm{Gu}} / J_{\mathrm{GyGu}, \mathrm{Gu}}\right)^{\left.\left.M_{\mathrm{GyGu}, \mathrm{Gu}}\right)\right]^{-1} .}\right.\right.
\end{aligned}
$$

Differential equation.

$$
\frac{d Q_{\mathrm{Gy}}}{d t}=P_{\mathrm{GuGy}}-U_{\mathrm{GyGu}}
$$

\section{Maintenance}

The maintenance requirements of the animal are calculated from Graham et al. (1976). From equations $2 a$ and $2 b$ the rate of body-weight gain is

$$
\frac{d W_{\text {body }}}{d t}=\frac{110}{0.215} \frac{d Q_{\mathrm{Pt}}}{d t}+890 \frac{d Q_{\mathrm{Tg}}}{d t} .
$$

The energy required for maintenance $\left(E_{\mathrm{Ma}}\right)$ is (Graham et al. 1976, p. 124)

$$
E_{\mathrm{Ma}}=0.257 W_{\mathrm{met}} e^{-0 \cdot 000219(t-98)}+2 \cdot 8 \frac{d W_{\text {body }}}{d t}+0.046 E_{\mathrm{dig}},
$$

where $W_{\text {met }}$ and $E_{\text {dig }}$ are given by equations 5 and $9 d$. This energy is provided at the expense of the ATP pool, giving an ATP utilization rate for maintenance of

$$
U_{\mathrm{Ma}, \mathrm{At}}=E_{\mathrm{Ma}} / E_{\mathrm{At}},
$$

where $E_{\mathrm{At}}$ is the energy content of ATP (MJ $\left./ \mathrm{kg} \mathrm{mol}\right)$, and is given by

$$
E_{\mathrm{At}}=77.3 \mathrm{MJ} / \mathrm{kg} \mathrm{mol} \text {. }
$$

Inputs.

$$
N A D P H \text { pool, } N p
$$

$$
P_{\mathrm{CzNp}}=Y_{\mathrm{CzNp}} U_{\mathrm{CzNp}} ; \quad P_{\mathrm{GuNp}}=Y_{\mathrm{GuNp}} U_{\mathrm{GuNp}} .
$$

Outputs.

$$
\begin{array}{ll}
U_{\mathrm{AaTg}, \mathrm{Np}}=R_{\mathrm{AaTg}, \mathrm{Np}} U_{\mathrm{AaTg}} ; & U_{\mathrm{CzTg}, \mathrm{Np}}=R_{\mathrm{CzTg}, \mathrm{Np}} U_{\mathrm{CzTg}} \\
U_{\mathrm{GuTg}, \mathrm{Np}}=R_{\mathrm{GuTg}, \mathrm{Np}} U_{\mathrm{GuTg}} ; & U_{\mathrm{PaTg}, \mathrm{Np}}=R_{\mathrm{PaTg}, \mathrm{Np}} U_{\mathrm{PaTg}} .
\end{array}
$$


Differential equation.

$$
\frac{d Q_{\mathrm{Np}}}{d t}=\text { inputs }- \text { outputs. }
$$

\section{Propionate pools, $\mathrm{Pa}$ and $\mathrm{Pl}$}

In ruminants, the majority of propionate metabolism occurs in the liver and only when the capacity of the liver to oxidize propionate or convert it to glucose is exceeded, do significant concentrations of propionate appear in hepatic blood (Bergman, 1975). In sheep, very high levels of propionate absorption lead to the incorporation of methyl malonyl CoA into fatty acid (Garton et al. 1972). Thus metabolism of propionate within the model is considered as two pools, with oxidation and gluconeogenesis occurring in the liver and triglyceride synthesis in adipose tissue. Transfer of propionate between the pools is effected by assuming a flow-rate of hepatic blood (Pethick et al. 1981).

For the adipose tissue, the only input term is

$$
P_{\mathrm{PlPa}}=v_{\mathrm{bfr}} C_{\mathrm{Pl}} \text {, }
$$

and the two output terms are

$$
\begin{aligned}
U_{\mathrm{PaPl}}= & v_{\mathrm{bfr}} C_{\mathrm{Pa}}, \\
U_{\mathrm{PaTg}}=W_{\mathrm{adip}} V_{\mathrm{PaTg}}\left(1+K_{\mathrm{PaTg}} / C_{\mathrm{Pa}}+\right. & K_{\mathrm{PaTg}, \mathrm{At}} / C_{\mathrm{At}} \\
& \left.+K_{\mathrm{PaTg}, \mathrm{Gu}} / C_{\mathrm{Gu}}+K_{\mathrm{PaTg}, \mathrm{Np}} / C_{\mathrm{Np}}\right)^{-1} .
\end{aligned}
$$

The differential equation for $\mathrm{Pa}$ is

$$
\frac{d Q_{\mathrm{Pa}}}{d t}=v_{\mathrm{brr}}\left(C_{\mathrm{Pl}}-C_{\mathrm{Pa}}\right)-U_{\mathrm{PaTg}} .
$$

For the liver pool, there are two inputs: the absorbed nutrient input $A_{\mathrm{Pl}}$ and

$$
U_{\mathrm{PaPl}}=v_{\mathrm{bPr}} C_{\mathrm{Pa}} \text {. }
$$

There are three outputs:

$$
\begin{aligned}
& U_{\mathrm{PlPa}}=v_{\mathrm{bfr}} C_{\mathrm{Pl}} \\
& U_{\mathrm{PICx}}=W_{\text {liver }} V_{\mathrm{PlCx}}\left(1+K_{\mathrm{PlCx}} / C_{\mathrm{Pl}}\right)^{-1}\left(1+C_{\mathrm{At}} / J_{\mathrm{PlCx}}\right)^{-1} \\
& U_{\mathrm{PlGu}}=W_{\text {liver }} V_{\mathrm{PIGu}}\left(1+K_{\mathrm{PlGu}} / C_{\mathrm{Pl}}+K_{\mathrm{PIGu}, \mathrm{At}} / C_{\mathrm{At}}\right)^{-1}\left(1+C_{\mathrm{Gu}} / J_{\mathrm{PlGu}}\right)^{-1} .
\end{aligned}
$$

The differential equation for $\mathrm{Pl}$ is

$$
\frac{d Q_{\mathrm{Pl}}}{d t}=A_{\mathrm{P} 1}+v_{\mathrm{bPr}}\left(C_{\mathrm{Pa}}-C_{\mathrm{Pl}}\right)-U_{\mathrm{PlCx}}-U_{\mathrm{PlGu}} \text {. }
$$

\section{Protein pool, $\mathrm{Pt}$}

The maximum rate of protein synthesis $\left(P_{\mathrm{Pt}, \max }\right)$ is assumed to be described by the empirical expression (Black \& Griffiths, 1975)

$$
P_{\mathrm{Pt}, \max }=0.001 \times(6.25 / 110)\left(2 \cdot 017 E_{\mathrm{met}}-0.401 W_{\mathrm{met}}-0.106 E_{\mathrm{met}} W_{\mathrm{met}}+0.024 W_{\mathrm{met}}{ }^{2}\right),
$$

where ME intake $\left(E_{\mathrm{met}}\right)$ and the metabolic weight $\left(W_{\mathrm{met}}\right)$ are given by equations $9 b$ and 5. Equation 50 allows the computation of $U_{\mathrm{AaPt}}$ in equation $17 \mathrm{~b}$. The production of protein is given by

$$
P_{\mathrm{AaPt}}=Y_{\mathrm{AaPt}} U_{\mathrm{AaPt}} \text {. }
$$


The protein laid down in wool and dermis must be subtracted from this. That laid down in wool is

$$
\frac{d \dot{Q}_{\mathrm{Pt}, \text { wool }}}{d t}=\left(\frac{6.25}{110}\right) \times 0.0016
$$

from Black \& Griffiths (1975, p. 404). That laid down in dermis is

$$
\frac{d Q_{\mathrm{Pt}, \mathrm{derm}}}{d t}=\left(\frac{6 \cdot 25}{110}\right) 0 \cdot 000018 W_{\mathrm{met}}
$$

from Agricultural Research Council (1980, p. 133). The differential equation for $Q_{\mathrm{Pt}}$ is therefore

$$
\frac{d Q_{\mathrm{Pt}}}{d t}=P_{\mathrm{AaPt}}-\frac{d Q_{\mathrm{Pt}, \text { wool }}}{d t}-\frac{d Q_{\mathrm{Pt}, \mathrm{derm}}}{d t}
$$

Triglyceride pool, $\mathrm{Tg}$

There is no dietary input of triglyceride as it is assumed that dietary lipid is broken down to fatty acid and glycerol during absorption.

Inputs.

$$
\begin{array}{ll}
P_{\mathrm{AaTg}}=Y_{\mathrm{AaTg}} U_{\mathrm{AaTg}} ; & P_{\mathrm{CzTg}}=Y_{\mathrm{CzTg}} U_{\mathrm{CzTg}} ; \\
P_{\mathrm{FaTg}}=Y_{\mathrm{FaTg}} U_{\mathrm{FaTg}} ; & P_{\mathrm{GuTg}}=Y_{\mathrm{GuTg}} U_{\mathrm{GuTg}} ; \\
P_{\mathrm{PaTg}}=Y_{\mathrm{PaTg}} U_{\mathrm{PaTg}} . &
\end{array}
$$

Output. It is assumed that adipose tissue turnover is accounted for in the empirical maintenance relationship (equation $40 a$ ), and therefore lipolysis ( $\mathrm{TgFa}$ ) only occurs at low ATP concentrations.

$$
U_{\mathrm{TgFa}}=W_{\mathrm{adip}} V_{\mathrm{TgFa}}\left[1+\left(K_{\mathrm{TgFa}} / C_{\mathrm{Tg}}\right)^{M_{\mathrm{TgFa}}}\right]^{-1}\left[1+\left(C_{\mathrm{At}} / J_{\mathrm{TgFa}, \mathrm{At}}\right)^{\left.M_{\mathrm{TgFa}, \mathrm{At}}\right]^{-1}}\right.
$$

Differential equation.

$$
\frac{d Q_{\mathrm{Tg}}}{d t}=\text { inputs }- \text { outputs. }
$$

\section{Urea (Ur) production}

The transactions producing urea are

$$
\begin{aligned}
& P_{\mathrm{AaCx}, \mathrm{Ur}}=Y_{\mathrm{AaCx}, \mathrm{Ur}} U_{\mathrm{AaCx}} ; \\
& P_{\mathrm{AaGu}, \mathrm{Ur}}=Y_{\mathrm{AaGu}, \mathrm{Ur}} U_{\mathrm{AaGu}} ; \\
& P_{\mathrm{AaTg}, \mathrm{Ur}}=Y_{\mathrm{AaTg}, \mathrm{Ur}} U_{\mathrm{AaTg}} .
\end{aligned}
$$

The rate of production of urea is the sum of these terms:

$$
\frac{d Q_{\mathrm{Ur}}}{d t}=P_{\mathrm{AaCx}, \mathrm{Ur}}+P_{\mathrm{AaGu}, \mathrm{Ur}}+P_{\mathrm{AaTg}, \mathrm{Ur}} \text {. }
$$

The energy associated with this urea excretion is

$$
E_{\mathrm{Ur}}=22.6 \times 0.47 \times 60 \frac{d Q_{\mathrm{Ur}}}{d t},
$$

where urea has $22.6 \mathrm{MJ} / \mathrm{kg} \mathrm{N}$, a $R M M$ of 60 and is $470 \mathrm{~g} \mathrm{~N} / \mathrm{kg}$. 


\section{Efficiencies and heat production}

The energy retained by the animal $\left(E_{\text {ret }}\right)$ is obtained by

$$
E_{\mathrm{ret}}=(R M M)_{\mathrm{Aa}} E_{\mathrm{Aa}} P_{\mathrm{AaPt}}+(R M M)_{\mathrm{Tg}} E_{\mathrm{Tg}} \frac{d Q_{\mathrm{Tg}}}{d t}+(R M M)_{\mathrm{Gu}} E_{\mathrm{Gu}} \frac{d Q_{\mathrm{Gy}}}{d t},
$$

where Table 5 (p. 636) and equations 51, 55 and 38 are used.

Heat production can be calculated in two ways, which gives a useful check on the formulation of the model. The following formula for the rate of heat production $\left(H_{1}\right)$ in $\mathrm{MJ} / \mathrm{d}$, based on Brouwer (1965), but ignoring methane production, is used:

$$
H_{1}=22.4\left(16.18 \frac{d Q_{\mathrm{Ox}}}{d t}+5.02 \frac{d Q_{\mathrm{Cx}}}{d t}\right)-28 \times 5.99 \times \frac{d Q_{\mathrm{Ur}}}{d t},
$$

with equations 27,25 and 57 . Heat production $\left(H_{2}\right)$ can also be estimated from the total energy balance by means of

$$
H_{2}=E_{\mathrm{abs}}-E_{\mathrm{ret}}-E_{\mathrm{Ur}},
$$

using equations $9 a, 59 a$ and 58 .

\section{Summary of model}

The model has twelve state variables (the quantities of $\mathrm{Aa}, \mathrm{Ac}, \mathrm{At}, \mathrm{Cz}, \mathrm{Fa}, \mathrm{Gu}, \mathrm{Gy}, \mathrm{Np}$, $\mathrm{Pa}, \mathrm{Pl}, \mathrm{Pt}$ and $\mathrm{Tg}$ ). There are twelve corresponding differential equations, which can be integrated for given initial conditions and parameter values. All other quantities of interest that lie within the scope of the model can be calculated from the state variables and their derivatives.

The basic assumption of the model is that each nutrient is partitioned between synthetic, oxidative, or intermediate reactions with rates of reactions which are described using enzyme kinetics. These rates are dependent on the relationship between constants of affinity and inhibition and the concentrations of metabolites as determined by the model. The potential rate of protein synthesis is independent of changes in the non-amino acid inputs, while the rate of fat synthesis is primarily limited by availability of the reduced co-factor NADPH. This reduced co-factor can be produced from both glucose and acetyl CoA with the former being the more important precursor. Thus, efficiency of utilization of absorbed nutrients is calculated from the energy input minus the heat production.

\section{NUMERICAL VALUES OF PARAMETERS}

\section{General}

In setting the kinetic parameters, initial consideration was given to the use of values derived from in vitro experiments; however, such values may not be suitable as optimal conditions for enzyme activity are not always known. There is a requirement for internal consistency between the parameters, and therefore the $V, J$ and $K$ parameters are set in relation to principles based on experimental results rather than from values determined in individual experiments. An assumption throughout the model is that all NADH produced in metabolic transactions yields 3 ATP via oxidative phosphorylation. Parameter values are assigned with a numerical precision of about $1 \%$, although biologically they are much less well defined.

Maximal reaction rates $(V)$. For triglyceride synthesis and for oxidation, it is assumed that any substrate can supply the required product at the maximal rate. 
Thus, all rates of triglyceride synthesis (AaTg, CzTg, FaTg, GuTg, PaTg) are related to a common maximal rate of fat deposition, $V_{\mathrm{Tg}}^{\prime}$, of

$$
V_{\mathrm{Tg}}^{\prime}=0.0347 \mathrm{~kg} \text { tristearin } / \mathrm{d} \text { per } \mathrm{kg} \text { body fat, }
$$

derived from a potential rate of energy deposition of a $25 \mathrm{~kg}$ Merino ram of $7.45 \mathrm{MJ} / \mathrm{d}$, of which 0.783 is deposited as fat (Black, 1983). This value is based on rams offered a balanced diet ad lib. Higher rates occur with heavier animals, different genotypes and unbalanced diets (Blaxter, 1976). $V_{\mathrm{Tg}}^{\prime}$ is increased by $33 \%$ to approximate a true $V$ (Black \& Reis, 1979), giving

$$
V_{\mathrm{Tg}}=V_{\mathrm{Tg}}^{\prime} /(0.75 \times 890)=52.4 \times 10^{-6} \mathrm{~kg} \mathrm{~mol} / \mathrm{d} \text { per kg adipose tissue, }
$$

where 890 is the relative molecular mass of tristearin.

Similarly, it is assumed that all oxidation reactions can occur at three times the maintenance rate (Blaxter, 1976), and $V_{\mathrm{At}}$ is defined as

$$
V_{\mathrm{At}}=3 \times E_{\mathrm{Ma}} /\left(E_{\mathrm{At}} W_{\text {body }}\right) \text {, }
$$

where $E_{\mathrm{At}}$ is the energy content of ATP. For a $25 \mathrm{~kg}, 177$-d-old sheep gaining $0.3 \mathrm{~kg} / \mathrm{d}$, and with a digestible energy intake of $16 \mathrm{MJ} / \mathrm{d}$, equation $40 a$ gives $E_{\mathrm{Ma}}=4.4 \mathrm{MJ} / \mathrm{d}$, and therefore

$$
V_{\mathrm{At}}=6.83 \times 10^{-3} \mathrm{~kg} \mathrm{~mol} \mathrm{ATP} / \mathrm{d} \text { per kg body tissue. }
$$

Most $V$ values are set in relation to $V_{\mathrm{Tg}}$ or $V_{\mathrm{At}}$. Values which are taken from experimental data but which are not directly related to $V_{\mathrm{Tg}}$ or $V_{\mathrm{At}}$ are increased by $33 \%$ as recommended by Black \& Reis (1979).

Affinity constants. From equation $1 a$ the affinity constant $K$ is given by

$$
K=\frac{s(V-U)}{U}
$$

where $s$ is substrate concentration, $V$ is the maximum rate and $U$ is the substrate utilization rate. Annison et al. (1967) report values for the percentage oxidation of different substrates, their relative contributions to carbon dioxide production, and total carbon dioxide production, giving a value of $9.85 \times 10^{-3} \mathrm{~kg}$ mol carbon dioxide $/ \mathrm{kg}$ body-weight ${ }^{0.75}$ per $\mathrm{d}$ for the latter. Fluxes can be calculated from these values for the oxidation reactions (Table 5); fluxes for the remaining reactions are calculated by assuming partitioning as described later.

Initial 'standard' concentrations are assumed for all substrates (Table 5), and the affinity constants for the primary substrates $\left(K_{i j}\right)$ are calculated relative to these values (columns two to five of Table 5 satisfy equation 63 , allowing for the tissue weight in which the reaction occurs (Tables 3 and 4)).

For the secondary substrates (ATP, glucose and NADPH), the affinity constants are related directly to initial concentrations: $K_{i j, \mathrm{At}}$ and $K_{i j, \mathrm{Gu}}$ are set at one-tenth of the normal At and $\mathrm{Gu}$ concentrations; $K_{i j, \mathrm{~Np}}$ is set equal to the normal Np concentration (Table 5). Referring to equation $1 b$, this gives greater limitation to fat synthesis by lack of $\mathrm{Np}$ than to lack of At or $\mathrm{Gu}$.

Inhibition constants. These are related to the concentrations of the inhibiting substances. For ATP and NADPH inhibition, the $J$ values are set equal to the initial concentrations. For gluconeogenesis, $J_{\mathrm{AaGu}}$ is set at one-half $\mathrm{Gu}$ (initial), whereas $J_{\mathrm{PlGu}}$ is twice $\mathrm{Gu}$ (initial), making gluconeogenesis from amino acids the less-favoured reaction (Judson \& Leng, 1973). 


\section{Stoichiometry and parameters of specific reactions and pools}

This section is to be read in conjunction with Tables 3,5 and 6 , and many parameter values can bo derived from the tables and chemical equations alone.

\section{Amino acid pool, $\mathrm{Aa}$}

The composition of the metabolic pool (not available for protein synthesis) is assumed equal to that of duodenal digesta (Oldham, 1981), with an average relative molecular mass of 110; an overall stoichiometry was calculated from the relative contributions of each individual amino acid (Schulz, 1978). Of the non-synthetic amino acid flux, an arbitrary $1 \%$ is attributed to triglyceride synthesis, and the remainder is partitioned $5: 1$ between oxidation and gluconeogenesis (estimated from Lindsay, 1976).

$\mathrm{AaCz}$.

$$
\text { Amino acid }+4.828 \mathrm{O}_{2}+23 \mathrm{ADP}+23 \mathrm{P}_{\mathrm{i}}=4.095 \mathrm{CO}_{2}+0.6 \text { urea }+23 \mathrm{ATP},
$$

where $P_{i}$ is inorganic phosphate.

Using equation $62 b$ and the preceding discussion

$$
V_{\mathrm{AaCx}}=V_{\mathrm{At}} / Y_{\mathrm{AaCx}, \mathrm{At}},
$$

giving the $V_{\mathrm{AaCx}}$ value in Table 5. $K_{\mathrm{AaCx}}$ is obtained by equation 63 using the amino acid concentration (Pion, 1976), the flux and $V_{\mathrm{AaCx}}$.

$A a G u$.

$$
\begin{aligned}
\text { Amino acid }+1.62 \mathrm{O}_{2}+4 \cdot 3 \mathrm{ADP}+4 \cdot 3 \mathrm{P}_{\mathrm{i}} \\
=0 \cdot 36 \text { glucose }+1 \cdot 18 \mathrm{CO}_{2}+4 \cdot 3 \mathrm{ATP}+0 \cdot 5 \text { urea. }
\end{aligned}
$$

It is assumed that this reaction supplies glucose when NADPH is short, relating $\mathrm{Gu}$ synthesis to $\mathrm{Np}$ synthesis from $\mathrm{Gu}$, and to the requirement for $\mathrm{Np}$ in the $\mathrm{CzTg}$ reaction. Thus

$$
V_{\mathrm{AaGu}}=\frac{V_{\mathrm{Tg}} R_{\mathrm{CzTg}, \mathrm{Np}}}{Y_{\mathrm{CzTg}} Y_{\mathrm{GuNp}} Y_{\mathrm{AaGu}}} .
$$

AaTg.

$$
\begin{array}{r}
\text { Amino acid }+2.045 \mathrm{O}_{2}+2.578 \mathrm{NADPH}+4.64 \mathrm{ADP}+0.027 \text { glucose }+4.64 \mathrm{P}_{\mathrm{i}} \\
=0.054 \text { tristearin }+1.33 \mathrm{CO}_{2}+2.578 \mathrm{NADP}+4.64 \mathrm{ATP}+0.6 \text { urea. }
\end{array}
$$

It is assumed that

$$
V_{\mathrm{AaTg}}=V_{\mathrm{Tg}} / Y_{\mathrm{AaTg}}
$$

$A c C z$.

$$
\mathrm{CH}_{3} \mathrm{COOH}+\mathrm{CoASH}+2 \mathrm{ATP}=\mathrm{CH}_{3} \mathrm{COSCoA}+2 \mathrm{ADP}+2 \mathrm{P}_{i}+\mathrm{H}_{2} \mathrm{O} .
$$

It is assumed that availability of CoASH is not limiting. It is assumed also that the main requirement for acetyl $\mathrm{CoA}$ is for oxidation, and therefore that

$$
V_{\mathrm{AcCz}}=V_{\mathrm{Cz} \mathbf{C x}} \text {. }
$$

The blood concentration of acetate (Annison et al. 1967) and an $\mathrm{AcCz}$ flux assumed equal to acetate absorption on a normal diet, enable $K_{\mathrm{AcCz}}$ to be calculated.

$A t D g$. For the ATP degradation reaction (equation $21 k$ ), it is assumed that $V_{\text {AtDg }}$ is three 
times $V_{\mathrm{At}}$, that $K_{\mathrm{AtDg}}$ is twice the initial At concentration, and that the sigmoidicity of the reaction $\left(M_{\mathrm{AtDg}}\right)$ is 4 . The initial concentration of ATP is defined as the mitochondrial concentration as determined by Reich \& Sel'kov (1981).

$\mathrm{BuCz}$.

$$
\mathrm{CH}_{3} \mathrm{CH}_{2} \mathrm{CH}_{2} \mathrm{COOH}+2 \mathrm{CoASH}+2 \mathrm{ADP}+2 \mathrm{P}_{\mathrm{i}}=2 \mathrm{CH}_{3} \mathrm{COSCoA}+2 \mathrm{ATP}+2 \mathrm{H}_{2} \mathrm{O} \text {. }
$$

The absorbed input of butyrate is directly converted to acetyl CoA as above.

$C z C x$.

$$
\begin{gathered}
\mathrm{CH}_{3} \mathrm{COSCoA}+2 \mathrm{O}_{2}+12 \mathrm{ADP}+12 \mathrm{P}_{\mathrm{i}}=2 \mathrm{CO}_{2}+\mathrm{H}_{2} \mathrm{O}+12 \mathrm{ATP}+\mathrm{CoASH} . \\
V_{\mathrm{CzCx}}=V_{\mathrm{At}} / Y_{\mathrm{CzCx}, \mathrm{At}} .
\end{gathered}
$$

The initial concentration of $\mathrm{Cz}$ is set equal to the initial concentration of acetate (Table 5); the total oxidation (i.e. $\mathrm{CzCx}$ plus $\mathrm{CzNp}$ ) is assumed to contribute $49 \%$ of total carbon dioxide production (Annison et al. 1967).

$$
\mathrm{CzN} \text {. }
$$

$\mathrm{CH}_{3} \operatorname{COSCoA}+1 \cdot 5 \mathrm{O}_{2}+\mathrm{NADP}+9 \mathrm{ADP}+9 \mathrm{P}_{\mathrm{i}}=$

$$
2 \mathrm{CO}_{2}+\mathrm{NADPH}+9 \mathrm{ATP}+\mathrm{CoASH} .
$$

While there is evidence from ruminant adipose tissue (Ballard et al. 1969; Bauman et al. $1973)$ that acetyl CoA can produce NADPH via the isocitrate dehydrogenase (EC 1.1.1.41 and 1.1.1.42) pathway, the rate of this reaction has been shown to limit fatty acid synthesis in the absence of glucose. Addition of glucose to in vitro preparations increases fatty acid synthesis by 3 - to 10 -fold (Vernon, 1981). Thus $V_{\mathrm{CzNp}}$ was set to give one-third the production of NADPH from $V_{\text {GuNp }}$ :

$$
V_{\mathrm{CzNp}}=\frac{V_{\mathrm{CzTg}} R_{\mathrm{CzTg}, \mathrm{Np}}}{3 Y_{\mathrm{CzNp}, \mathrm{Np}}} \times \frac{W_{\mathrm{adip}}}{\left(W_{\mathrm{adip}}+W_{\text {liver }}\right)} .
$$

To calculate $K_{\mathrm{CzNp}}, \mathrm{CzNp}$ is assumed to provide one-sixth of the NADPH provided by GuNp.

$C z T g$.

$\mathrm{CH}_{3} \mathrm{COSCoA}+0.019$ glucose $+1 \cdot 15 \mathrm{ATP}+1 \cdot 78 \mathrm{NADPH}$

$$
\begin{gathered}
=0.0370 \text { tristearin }+1 \cdot 15 \mathrm{ADP}+1 \cdot 78 \mathrm{NADP}+\mathrm{CoASH}+1 \cdot 15 \mathrm{P}_{\mathrm{i}} . \\
V_{\mathrm{CzTg}}=V_{\mathrm{Tg}} / Y_{\mathrm{CzTg}} .
\end{gathered}
$$

The CzTg flux is assumed to be $52 \%$ of the total flux out of the $\mathrm{Cz}$ pool (Annison et al. 1967).

$\mathrm{FaCx}$.

$$
\begin{gathered}
\mathrm{C}_{17} \mathrm{H}_{35} \mathrm{COOH}+26 \mathrm{O}_{2}+146 \mathrm{ADP}+146 \mathrm{P}_{1}=18 \mathrm{CO}_{2}+146 \mathrm{ATP}+18 \mathrm{H}_{2} \mathrm{O} . \\
V_{\mathrm{FaCx}}=V_{\mathrm{At}} / Y_{\mathrm{FaCx}, \mathrm{At}} .
\end{gathered}
$$

$K_{\mathrm{FaCx}}$ is calculated from $V_{\mathrm{FaCx}}$, the initial concentration of $\mathrm{Fa}$ (Annison et al. 1967) and the flux, assuming that $\mathrm{FaCx}$ contributes $4 \%$ of total carbon dioxide production (Annison et al. 1967). 
FaTg.

Stearic acid $+0 \cdot 167$ glucose $+2 \cdot 33 \mathrm{ATP}=0 \cdot 33$ tristearin $+2 \cdot 33 \mathrm{ADP}+2 \cdot 33 \mathrm{P}_{\mathbf{i}}$.

$$
V_{\mathrm{FaTg}}=\frac{V_{\mathrm{Tg}}}{Y_{\mathrm{FaTg}}} \times \frac{W_{\text {adip }}}{\left(W_{\text {adip }}+W_{\text {liver }}\right)} .
$$

For calculating $K_{\mathrm{FaTg}}$, it is assumed that $63 \%$ of the total non-oxidized fatty acid flux is used for fat synthesis (Annison et al. 1967).

GuCx.

$$
\begin{gathered}
\text { Glucose }+38 \mathrm{ADP}+38 \mathrm{P}_{\mathrm{i}}+6 \mathrm{O}_{2}=6 \mathrm{CO}_{2}+6 \mathrm{H}_{2} \mathrm{O}+38 \mathrm{ATP} . \\
V_{\mathrm{GuCx}}=V_{\mathrm{At}} / Y_{\mathrm{GuCx}, \mathrm{At}} .
\end{gathered}
$$

$K_{\mathrm{GuCx}}$ is calculated from $V_{\mathrm{GuCx}}$, the initial concentration of glucose (Annison et al. 1967) and the flux of glucose through the Krebs cycle, assuming that glucose oxidation contributes $20 \%$ to total carbon dioxide production. Values of approximately $20 \%$ are suggested by Annison \& White (1961) and Judson et al. (1976). This is higher than the value suggested by Annison et al. (1967) but the results of the latter are insufficient to account for glucose oxidation under the restrictions on glucose metabolism imposed by the model.

GuGy.

$$
\text { Glucose }+2 \mathrm{ATP}=\text { glycogen }+2 \mathrm{ADP}+2 \mathrm{P}_{\mathrm{i}} .
$$

The maximum value of glycogen storage $\left(Q_{\mathrm{Gy}}\right.$, max $)$ is set at $2 \%$ of muscle weight (McVeigh \& Tarrant, 1982) and 6\% of liver weight (Leng \& Annison, 1963), increased by one-third as recommended by Black \& Reis (1979). Similarly, $V_{\text {GuGy }}$ was calculated from the values of McVeigh \& Tarrant (1982) (see Table 5). $K_{\mathrm{GuGy}}$ is calculated assuming the flux is half maximal.

GuNp.

$$
\text { Glucose + 12NADP + ATP }+6 \mathrm{H}_{2} \mathrm{O}=6 \mathrm{CO}_{2}+12 \mathrm{NADPH}+\mathrm{ADP}+\mathrm{P}_{\mathrm{i}} \text {. }
$$

The main requirement for NADPH is for the synthesis of triglyceride from acetyl CoA and thus $V_{\mathrm{GuNp}}$ is related to $V_{\mathrm{CzTg}}$ by

$$
V_{\mathrm{GuNp}}=\frac{V_{\mathrm{CzTg}} R_{\mathrm{CzTg}, \mathrm{Np}}}{Y_{\mathrm{GuNp}}}
$$

$K_{\mathrm{GuNp}}$ is calculated assuming that oxidation by the pentose-phosphate pathway is 3.5 times greater than by the Krebs cycle (GuCx) (Yang et al. 1982).

GuTg.

$$
\begin{gathered}
\text { Glucose + 3.56NADPH }+9 \cdot 70 \mathrm{ADP}+9 \cdot 70 \mathrm{P}_{\mathrm{i}}+2 \mathrm{O}_{2} \\
=0 \cdot 0714 \text { tristearin }+3 \cdot 56 \mathrm{NADP}+9 \cdot 70 \mathrm{ATP}+2 \mathrm{CO}_{2}+2 \mathrm{H}_{2} \mathrm{O} . \\
V_{\mathrm{GuTg}}=\frac{V_{\mathrm{Tg}}}{Y_{\text {GuTg }}} \times \frac{W_{\text {adip }}}{\left(W_{\text {adip }}+W_{\text {liver }}\right)} .
\end{gathered}
$$

$K_{\mathrm{GuTg}}$ is calculated assuming that the flux of glucose is $1 \%$ of the total flux of glucose to oxidation.

$G y G u$. The relative molecular mass of glycogen is assumed to be the same as for glucose, i.e. 180. Glycogenolysis occurs without release of energy and with 1 mol glucose production $/ \mathrm{mol}$ of glycogen metabolized. To calculate $V_{\mathrm{GyGu}}$ it is assumed that a maximum 
of $50 \%$ of muscle glycogen and $85 \%$ of liver glycogen can be released per day (Sugden et al. 1976; McVeigh \& Tarrant, 1982). This reaction is sigmoidal in form, with the potential to operate at the maximum rate until the glycogen store is depleted to approximately $10 \%$ of its maximum, i.e. $16.6 \times 10^{-3} \mathrm{~kg}$. Thus (see Table 4)

$$
K_{\mathrm{GyGu}}=\frac{16.6 \times 10^{-3}}{180 v_{\mathrm{bld}}} .
$$

Initial glycogen concentration is assumed to be half the maximal amount divided by initial blood volume. Inhibition of glycogenolysis by glucose concentration is also assumed to be sigmoidal $(M=4)$ with inhibition commencing at half the initial glucose concentration.

$N p$. The initial concentration of NADPH is calculated from values presented by Reich \& Sel'kov (1981) who measured NADPH is muscle and liver. Their value for the concentration per $\mathrm{kg}$ tissue is assumed to be equivalent to a concentration per $\mathrm{m}^{3}$ blood as represented in the model.

$$
\text { PaTg. }
$$

$\mathrm{C}_{5} \mathrm{H}_{5} \mathrm{COOH}+0 \cdot 0185$ glucose $+1 \cdot 78 \mathrm{NADPH}+4 \cdot 15 \mathrm{ATP}+\mathrm{CO}_{2}$

$$
=0.037 \text { triglyceride }+1 \cdot 78 \mathrm{NADP}+4 \cdot 15 \mathrm{ADP}+4 \cdot 15 \mathrm{P}_{i} \text {. }
$$

While this equation gives the theoretical yield of triglyceride composed entirely of methyl-malonyl moieties, Duncan \& Garton (1978) suggested that a maximum of three methyl-malonyl CoA molecules are incorporated into one molecule of fatty acid, i.e. nine methyl-malonyl CoA molecules into 1 molecule of triglyceride, and thus

$$
V_{\mathrm{PaTg}}=V_{\mathrm{Tg}} \times 9 .
$$

$\mathrm{K}_{\mathrm{PaTg}}$ is calculated from $V_{\mathrm{PaTg}}$, the initial concentration of propionate in adipose tissue (Bergman, 1975), and by assuming that the flux of PaTg is $1 \%$ of the propionate flux.

PlCx.

$$
\begin{gathered}
\mathrm{C}_{2} \mathrm{H}_{5} \mathrm{COOH}+3 \cdot 5 \mathrm{O}_{2}+21 \mathrm{ADP}+21 \mathrm{P}_{\mathrm{i}}=3 \mathrm{CO}_{2}+3 \mathrm{H}_{2} \mathrm{O}+21 \mathrm{ATP} . \\
V_{\mathrm{PlCx}}=\frac{V_{\mathrm{At}}}{Y_{\mathrm{PlCx}, \mathrm{At}}} \times \frac{W_{\text {body }}}{W_{\text {liver }}} .
\end{gathered}
$$

$K_{\mathrm{PICx}}$ is calculated from $V_{\mathrm{PICx}}$, the initial propionate concentration (Bergman, 1975) and by assuming the percentage of propionate directly oxidized to represent that which is not converted to glucose, i.e. $69 \%$.

$P I G u$.

$$
\begin{gathered}
\mathrm{C}_{2} \mathrm{H}_{5} \mathrm{COOH}+0 \cdot 5 \mathrm{O}_{2}+2 \mathrm{ATP}=0 \cdot 5 \text { glucose }+2 \mathrm{ADP}+2 \mathrm{P}_{\mathrm{i}} . \\
V_{\mathrm{PIGu}}=V_{\mathrm{GuNp}} / Y_{\mathrm{PlGu}, \mathrm{Gu}} .
\end{gathered}
$$

It is assumed that gluconeogenesis only operates when glucose is required to supply NADPH for fatty acid synthesis. $K_{\mathrm{PIGu}}$ is calculated by assuming that $30 \%$ of total propionate flux is converted to glucose (Elliott, 1980). The sensitivity of the model to this parameter will be considered further in a subsequent paper.

\section{Protein pool, $\mathrm{Pt}$}

The initial amount of protein within the sheep is calculated from the equation of Searle \& Griffiths (1976) for predicting body protein in relation to body-weight and weight at which fattening commences:

$$
Q_{\mathrm{Pt}}=\left\{0 \cdot 26+0.0235 \mathrm{~W}_{\text {fatt }}+0 \cdot 1085 \times W_{\text {body }}+0 \cdot 235\left[\left(W_{\text {body }}-W_{\text {fatt }}\right)^{2}+33\right]^{0.5}\right\} / 110,
$$


where $W_{\text {fatt }}$ is the body-weight at which the fattening phase of growth starts, which is a function of genotype; here $W_{\text {fatt }}=30 \mathrm{~kg}$ (Black, 1983).

The energy cost (in terms of ATP) of protein deposition is assumed to be $20 \mathrm{~kJ} / \mathrm{g}$ protein synthesized (Lobley \& Reeds, 1980).

\section{Triglyceride pool $(\mathrm{Tg})$}

The initial amount of triglyceride within the animal is assumed to be equal to the amount of fat which, as for protein, is calculated from an equation reported by Searle \& Griffiths (1976):

$$
Q_{\mathrm{Tg}}=\left\{-0.85-0.235 W_{\text {fatt }}+0.415 W_{\text {body }}+0.235\left[\left(W_{\text {body }}-W_{\text {fatt }}\right)^{2}+33\right]^{0.5}\right\} / 890 .
$$

$\mathrm{TgFa}$.

$$
\text { Tristearin }=3 \text { stearic acid }+0 \cdot 5 \text { glucose. }
$$

$V_{\mathrm{TgFa}}$ is set to account for eight times maintenance ATP requirement, since sheep under cold stress can produce heat at six times maintenance (Graham et al. 1976), and this is increased by one-third to approximate a maximum. Thus:

$$
V_{\mathrm{TgFa}}=\frac{8 U_{\mathrm{AtMa}}}{Y_{\mathrm{FaCx}, \mathrm{At}} Y_{\mathrm{TgFa}} W_{\mathrm{adip}}} .
$$

$K_{\mathrm{TgFa}}$ is set such that when the fat depot is only $2 \%$ of body-weight, the rate of lipolysis decreases rapidly $(M=20)$. The rate of TgFa is also controlled by the concentration of ATP, inhibited sigmoidally $(M=4)$ when ATP is greater than one-tenth of its initial concentration.

\section{Urea production}

The energy cost of urea synthesis is included in the ATP requirements for the catabolic reactions of amino acids. The energy cost of urea excretion is calculated using the value suggested by Martin \& Blaxter (1965).

\section{Integration method and stability}

Integration intervals of $\Delta t=0.0005$ and $0.0002 \mathrm{~d}$ (43 and $17 \mathrm{~s}$ respectively) were used, with a fourth-order fixed-step-length Runge-Kutta method. After an initial transient value, the solutions quickly settled down to values which thereafter changed only slowly. The model does not have any true exponential growth solutions. The results were obtained by taking the predictions of the model at $2 \mathrm{~d}$. The equations are to an extent stiff, and the quasi-stability of the system was much improved by artificially increasing the volumes of the At, $\mathrm{Np}$ and $\mathrm{Pl}$ pools by a factor of ten. This does not alter significantly the quasi-steady-state solutions. The solutions were not sensitive to integration method or interval (in the stable region), nor to changes in the initial values of the twelve state variables (essentially the pool concentrations). The problem is programmed in the modelling languages CSMP (Speckhart \& Green, 1976) and ACSL (Mitchell \& Gauthier, 1981).

\section{RESULTS}

The model has been used to study the effect of a wide variety of nutrient inputs on the efficiency of energy utilization for growth $(k) . k$ is used to denote the marginal efficiency, equal to the increment in energy retention divided by the increment in the calculated ME. The results presented relate to the efficiency of different combinations of nutrients. Results on the partial efficiencies for individual nutrients will be presented in a later paper (J. L. Black, M. Gill, J. H. M. Thornley, D. E. Beever and J. D. Oldham, unpublished results). 
Table 7. Nutrient inputs for basal level of simulations presented in Fig. 2

\begin{tabular}{|c|c|c|c|}
\hline & $\mathrm{g} \mathrm{mol} / \mathrm{d}$ & $\mathrm{MJ} / \mathrm{d}$ & $\begin{array}{c}\% \text { of total } \\
\text { absorbed } \\
\text { energy }\end{array}$ \\
\hline \multicolumn{4}{|c|}{ Diet* a (concentrate type) $^{*}$} \\
\hline Acetic acid & 3.090 & $2 \cdot 707$ & $30 \cdot 9$ \\
\hline Amino acids & 0.692 & $1 \cdot 751$ & $20 \cdot 0$ \\
\hline Butyric acid & 0.520 & $1 \cdot 139$ & $13 \cdot 0$ \\
\hline Glucose & $0 \cdot 152$ & 0.438 & $5 \cdot 0$ \\
\hline Lipid & $0 \cdot 010$ & $0 \cdot 350$ & $4 \cdot 0$ \\
\hline Propionic acid & $1 \cdot 550$ & $2 \cdot 386$ & $27 \cdot 2$ \\
\hline \multicolumn{4}{|c|}{ Diet* b (forage type) } \\
\hline Acetic acid & 4.990 & $4 \cdot 371$ & $49 \cdot 8$ \\
\hline Amino acids & 0.350 & 0.886 & $10 \cdot 1$ \\
\hline Butyric acid & 0.480 & 1.048 & $11 \cdot 9$ \\
\hline Glucose & 0.0 & 0.0 & $0 \cdot 0$ \\
\hline Lipid & 0.010 & 0.350 & $4 \cdot 0$ \\
\hline Propionic acid & $1 \cdot 370$ & $2 \cdot 119$ & $24 \cdot 2$ \\
\hline
\end{tabular}

* For details of diets, see below.

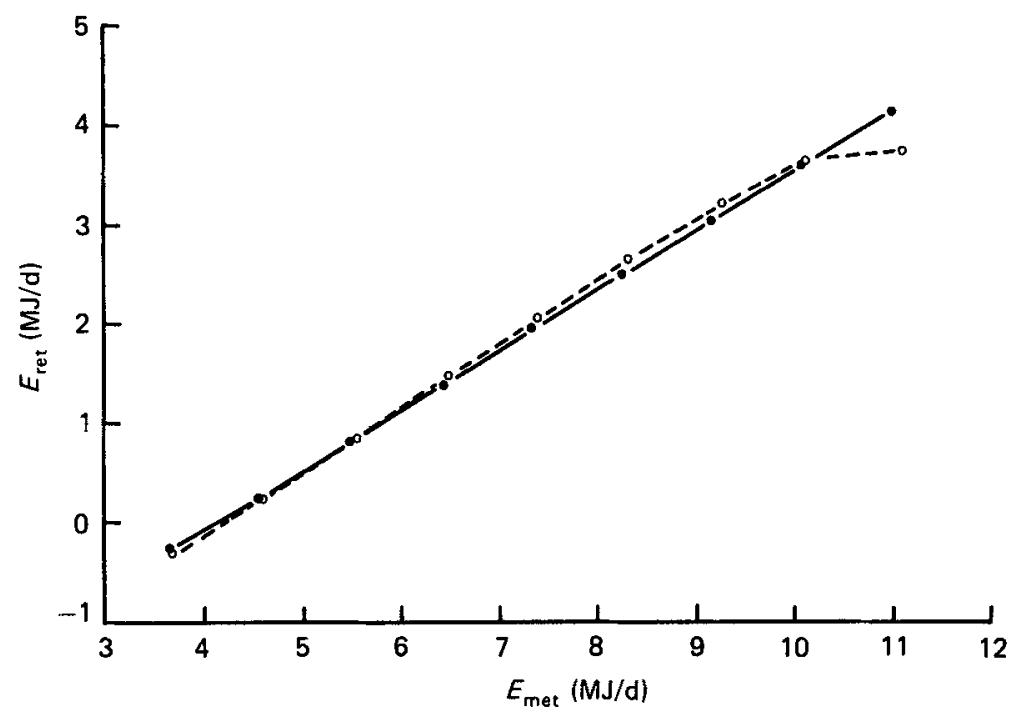

Fig. 2. Simulated response of energy retention ( $E_{\text {ret, }}$, equation $59 a$ ) to metabolizable energy intake ( $E_{\text {met }}$, equation $9 b$ ). ( - Diet a, $20 \%$ protein and $5 \%$ glucose, concentrate-type volatile fatty acids (VFA). (--) Diet $b, 10 \%$ protein and $0 \%$ glucose, forage-type VFA.

Two combinations of nutrients were chosen to reflect likely patterns of nutrient supply from extreme 'diets'. Both supplied $4 \%$ of the absorbed energy as lipid; diet a had a high-protein, high-glucose and volatile fatty acids (VFA) pattern typical of animals fed on concentrates, while diet $\mathrm{b}$ supplied low protein, no glucose and a forage-type VFA pattern. The molar proportions of VFA were taken from the values for $10 \%$ and $100 \%$ hay diets reported by Sutton \& Morant (1979). The VFA provided $71 \%$ of $E_{\text {abs }}$ (absorbed energy) on diet a and $86 \%$ on diet b. The inputs which provided $8.75 \mathrm{MJ}$ absorbed energy/d are shown in Table 7, other inputs were calculated as multiples of these values. The relationship between ME intake (MEI) and energy retained is shown in Fig. 2. The energy 


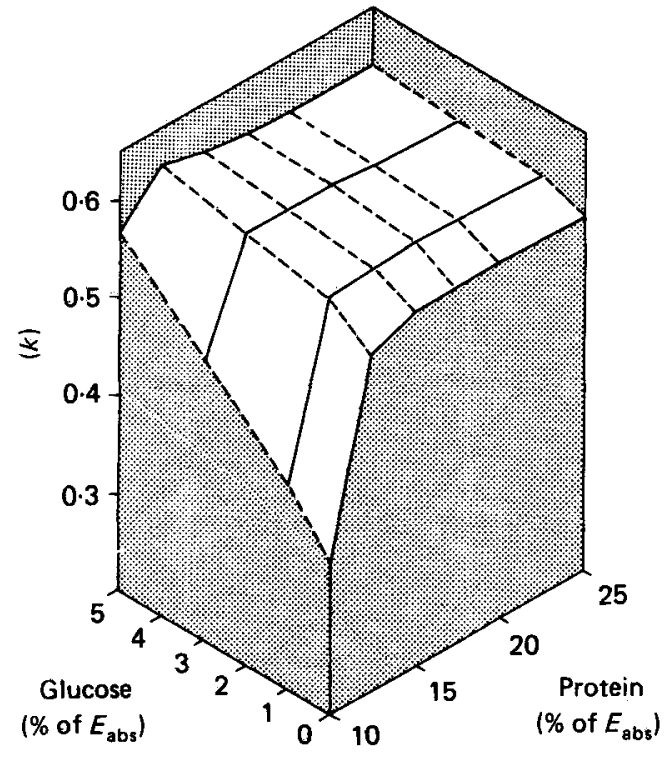

Fig. 3.

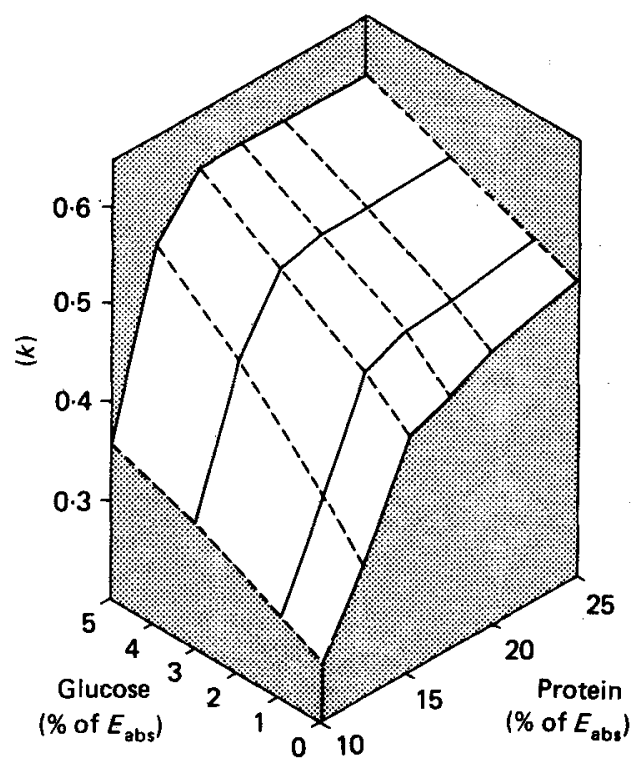

Fig. 4.

Fig. 3. Simulated response in efficiency of energy utilization for growth $(k)$ to protein and glucose (both as $\%$ of absorbed energy) increasing from 10 to $25 \%$ and 0 to $5 \%$ respectively. Metabolizable energy intake increases from 8.75 to $9.63 \mathrm{MJ} / \mathrm{d}$.

Fig. 4. Simulated response in efficiency of energy utilization for growth $(k)$ to protein and glucose (both as \% of absorbed energy) increasing from 10 to $25 \%$ and 0 to $5 \%$ respectively. Metabolizable energy intake increases from 9.63 to $10.5 \mathrm{MJ} / \mathrm{d}$.

required for zero energy balance was calculated to be $4 \cdot 1 \mathrm{MJ} / \mathrm{d}$. The incremental efficiency of ME utilization $(k)$ when MEI increased from 4.6 to $6.9 \mathrm{MJ} / \mathrm{d}$ was $60.4 \%$ for diet a and $65.1 \%$ for diet $b$. However, the incremental efficiencies decreased to 57.2 and $26.2 \%$ for diets $a$ and $b$ respectively when MEI increased from 10.1 to $11.0 \mathrm{MJ} / \mathrm{d}$.

The effect of the change in efficiency with MEI is further demonstrated by the difference in response to protein and glucose between Figs. 3 and 4. These figures show the response, in terms of efficiency, to protein increasing from 10 to $25 \%$ of $E_{\text {abs }}$ with glucose representing $0,10,30$ and $50 \mathrm{~kJ} / \mathrm{MJ} E_{\mathrm{abs}}$. The molar proportions of the VFA were kept constant at 73:20:7 and lipid provided a constant $4 \%$ of the $E_{\text {abs. }}$. Fig. 3 shows the incremental efficiency when $E_{\text {abs }}$ was increased from 8.75 to $9.63 \mathrm{MJ} / \mathrm{d}$ and Fig. 4 when $E_{\text {abs }}$ was increased from 9.63 to $10.5 \mathrm{MJ} / \mathrm{d}$ using forage-type VFA inputs. These ranges of energy input were chosen to correspond with the most sensitive area of the relationship shown in Fig. 2. Efficiency was always higher at the lower energy intake and increased in response to increasing glucose. As protein increased, efficiency increased to a maximum and then decreased slightly, the optimum protein level decreasing as glucose increased. This depression is more obvious in the values for energy retention (Table 8). Energy retention increased with increasing glucose but decreased with increasing protein.

\section{DISCUSSION}

One of the objectives in developing this model was to assess how much of the variability in efficiency of ME utilization could be attributed to differences in the balance of nutrients supplied. Synthesis of protein is assumed to be unaffected by the balance of energy-yielding 
Table 8. The effect of changing the level of energy absorbed and the proportions of protein and glucose in the absorbed energy $\left(\mathrm{E}_{\text {abs }}\right)$ on calculated energy retention $(M J / d)$

\begin{tabular}{|c|c|c|c|c|c|}
\hline \multirow{2}{*}{$\begin{array}{l}\text { Amino acid } \\
\text { input } \\
\left(\% \text { of } E_{\mathrm{abs}}\right)\end{array}$} & \multirow{2}{*}{$\begin{array}{c}E_{\text {abs }} \\
(\mathrm{MJ} / \mathrm{d})\end{array}$} & \multicolumn{4}{|c|}{ Energy retained (MJ/d) } \\
\hline & & $0^{*}$ & $1^{*}$ & $3^{*}$ & $5^{*}$ \\
\hline 10 & $\begin{array}{r}8 \cdot 75 \\
9.63 \\
10 \cdot 50\end{array}$ & $\begin{array}{l}3 \cdot 19 \\
3 \cdot 53 \\
3 \cdot 77\end{array}$ & $\begin{array}{l}3.21 \\
3.59 \\
3.85\end{array}$ & $\begin{array}{l}3 \cdot 27 \\
3 \cdot 72 \\
4 \cdot 02\end{array}$ & $\begin{array}{l}3 \cdot 32 \\
3 \cdot 84 \\
4 \cdot 18\end{array}$ \\
\hline $12 \cdot 5$ & $\begin{array}{r}8.75 \\
9.63 \\
10.50\end{array}$ & $\begin{array}{l}3 \cdot 05 \\
3 \cdot 55 \\
3 \cdot 86\end{array}$ & $\begin{array}{l}3.07 \\
3.60 \\
3.95\end{array}$ & $\begin{array}{l}3 \cdot 11 \\
3 \cdot 66 \\
4 \cdot 10\end{array}$ & $\begin{array}{l}3 \cdot 14 \\
3 \cdot 71 \\
4 \cdot 21\end{array}$ \\
\hline 15 & $\begin{array}{r}8.75 \\
9.63 \\
10.50\end{array}$ & $\begin{array}{l}2.96 \\
3.49 \\
3.90\end{array}$ & $\begin{array}{l}2.98 \\
3.51 \\
3.96\end{array}$ & $\begin{array}{l}3.00 \\
3.55 \\
4.05\end{array}$ & $\begin{array}{l}3.03 \\
3.58 \\
4 \cdot 12\end{array}$ \\
\hline $17 \cdot 5$ & $\begin{array}{r}8.75 \\
9.63 \\
10.50\end{array}$ & $\begin{array}{l}2.93 \\
3.45 \\
3.87\end{array}$ & $\begin{array}{l}2.93 \\
3.46 \\
3.92\end{array}$ & $\begin{array}{l}2 \cdot 96 \\
3 \cdot 50 \\
4 \cdot 01\end{array}$ & $\begin{array}{l}2 \cdot 99 \\
3 \cdot 54 \\
4 \cdot 08\end{array}$ \\
\hline 20 & $\begin{array}{r}8.75 \\
9.63 \\
10 \cdot 50\end{array}$ & $\begin{array}{l}2.87 \\
3.39 \\
3.83\end{array}$ & $\begin{array}{l}2.88 \\
3.42 \\
3.88\end{array}$ & $\begin{array}{l}2.93 \\
3.47 \\
3.98\end{array}$ & $\begin{array}{l}2 \cdot 94 \\
3 \cdot 48 \\
4 \cdot 01\end{array}$ \\
\hline 25 & $\begin{array}{r}8.75 \\
9 \cdot 63 \\
10 \cdot 50\end{array}$ & $\begin{array}{l}2.79 \\
3.31 \\
3.77\end{array}$ & $\begin{array}{l}2 \cdot 80 \\
3 \cdot 32 \\
3 \cdot 80\end{array}$ & $\begin{array}{l}2 \cdot 83 \\
3 \cdot 37 \\
3 \cdot 88\end{array}$ & $\begin{array}{l}2 \cdot 86 \\
3 \cdot 40 \\
3 \cdot 93\end{array}$ \\
\hline
\end{tabular}

* Glucose input ( $\%$ of $\left.E_{\mathrm{abs}}\right)$.

nutrients other than amino acids, since animals are observed to continue to gain protein while losing fat at energy intakes close to maintenance (Black, 1974). The proportion of energy which is retained by the animal is determined by the efficiency with which acetate, propionate, fatty acids, glucose and the amino acids surplus to protein requirements, are converted to triglyceride. This requires consideration of ATP and NADPH as key metabolites within the model and their production and utilization are best described using established stoichiometric relationships.

\section{ATP degradation and model stability}

During initial runs of the model, ATP tended to accumulate, particularly at high input levels of unbalanced 'diets', e.g. low protein or zero glucose inputs, or both. To achieve stability, a function AtDg was introducted which removed ATP from the system, using a sigmoidal relationship which switches on when ATP concentration is twice the initial value. The rate of this reaction normally accounts for less than $2 \%$ of $\mathrm{ME}$ input, but a maximum value of $6 \%$ is reached when protein input is $10 \%$ of $E_{\mathrm{abs}}$ and glucose input is zero, at an ME input of $11.1 \mathrm{MJ} / \mathrm{d}$ or $1 \mathrm{MJ} / \mathrm{kg}$ body weight ${ }^{0.75}$ per $\mathrm{d}$. This level of intake is unlikely to be reached voluntarily by sheep offered diets low in protein (Egan, 1977). As might be expected, the rate of AtDg increases with increasing energy input, the rate of increase being greater in those situations where protein or glucose represent low proportions of total $E_{\text {abs }}$ (i.e. unbalanced diets). If AtDg is taken as representative of futile cycles within the animal, this may suggest that there is a maximum rate of futile cycling above which voluntary intake will be limited. Increasing or decreasing the concentration at which AtDg switches on $\left(K_{\text {AtDg }}\right)$ by a factor of $50 \%$, changed energetic efficiency by less than 5 percentage units. 


\section{NADPH production}

The obligatory requirement for NADPH in the synthesis of long-chain fatty acids was suggested by Armstrong \& Blaxter (1961) and Armstrong (1965) as a possible limitation to the efficiency with which acetate is used, assuming that glucose is the major precursor for NADPH production. Earlier work by Blaxter, Armstrong and co-workers (Armstrong \& Blaxter, 1957; Armstrong et al. 1958) had demonstrated a higher heat increment, i.e. a lower efficiency in response to intra-ruminal infusion of acetate, compared with infusion of propionate or butyrate, but the results of subsequent experiments did not always confirm these findings (Rook et al. 1963; Ørskov \& Allen, 1966; Hovell et al. 1976). One of the objectives of the model was to represent mathematically the hypothesis referred to by Hovell et al. (1976) and McRae \& Lobley (1982), that these differences in the efficiency with which acetate is used reflect differences in the supply of glucogenic precursors, i.e. that a low availability of glucose limits the rate of NADPH production and hence the rate of fatty acid synthesis from acetate. The model simulates this sequence of events by including an affinity constant for NADPH concentration in the reaction $\mathrm{CzTg}$ whereby acetyl CoA is converted to triglyceride (equation $15 \mathrm{c}$ ). With this representation, simulations show low efficiencies of energy utilization when the supply of glucose or glucose precursors is low relative to the supply of acetate and thus lends support to the proposed hypothesis. The model does not provide a unique test of the hypothesis since alternative representations have not been considered. It does provide a mechanism for examining the effects of varying nutrient supply on energy retention which takes account of the relationship between glucose and acetate metabolism.

\section{Simulation of energy utilization}

Evaluation of the model in relation to the effect of diets on efficiency of energy utilization presented two major problems. Firstly, although there are numerous reports on the flow of total organic matter and protein into the duodenum on a variety of diets, the majority of these do not record VFA production rates nor the absorptions of protein, lipid and glucose. Where complete nutrient profiles are available, these generally correspond to one feeding level, while estimation of $k_{f}$ conventionally requires measurement at more than one feeding level. Consequently, it was not possible to find complete sets of test data from individual published experiments and the inputs presented in Table 7 are values chosen to represent forage- and concentrate-type diets. Secondly, experimental values for the efficiency with which dietary energy is retained show considerable variation even within diet. Thomson et al. (1979) reported values for $k_{f}$ ranging from 28 to $54 \%$ for lambs offered diets of dried perennial ryegrass (Lolium perenne) fed in the chopped form. The Agricultural Research Council (1980) suggests a range of efficiencies for forage diets from 0.16 for a forage regrowth of low metabolizability to 0.61 for a primary growth forage of high metabolizability, while Blaxter (1961) gave a range of efficiencies for fattening from 30 to $64 \%$ for diets of poor hay through to starchy concentrates. The values obtained from the model of $54 \%$ for 'forage' inputs and $60 \%$ for 'concentrate' inputs fall within the range of experimental values and reflect an increase in efficiency with a presumed increase in metabolizability from the 'forage' to the 'concentrate' diet. With the simulated forage inputs efficiency decreased with MEI greater than $8 \mathrm{MJ} / \mathrm{d}$, suggesting a curvilinear response. For experimentally derived relationships, Blaxter \& Wainman (1961) reported no significant deviation from a linear response but D. J. Thomson (personal communication) observed a decreased efficiency with high intakes of pelleted diets. A more detailed study of the model outputs enables interpretation of the reasons why the simulated efficiencies decreased as energy intake increased. This decrease was due to a change in type of energy-yielding nutrients required at different energy intakes. At simulated low energy intakes, the main energy requirement was ATP for maintenance (AtMa) and protein 
synthesis (AtPt). Within the model, these two processes are described by empirical relationships and thus have priority over transactions described by Michaelis-Menten kinetics. As energy input to the model increases, the ratio, fat:protein deposition increases, as does the synthesis of triglyceride from acetyl CoA. This reaction requires NADPH and thus the ratio, NADPH:ATP required increases as energy intake increases. If production of NADPH is limiting, then the rate of fat synthesis will be restricted and efficiency will decrease. Experimental evidence for this direct relationship is not available. However, there are reports that lack of glucose can limit the rate of long-chain fatty acid synthesis in vitro (Ballard et al. 1972; Yang \& Baldwin, 1973). In addition, there is evidence that an increase in flow of $\alpha$-linked glucose polymers to the small intestine may be associated with increased growth rate in cattle offered diets which induce a low propionate fermentation (Preston $e t$ al. 1976; Elliot et al. 1978; Lopez \& Preston, 1978).

The change in efficiency with energy input can also be seen in the comparison betwen Figs. 3 and 4. Efficiency is always lower at the higher energy level (Fig. 4). As discussed earlier, efficiency increases with increasing glucose supply as a result of increased NADPH production. This response decreases in response to increasing protein supply owing to an increase in the ratio, protein:fat deposition, which increases the utilization of ATP for peptide-bond synthesis and decreases the rate of fat synthesis, thus decreasing the requirement for NADPH. Once protein supply is greater than the potential rate of protein synthesis $\left(P_{\mathrm{Pt} \text { max }}\right)$, efficiency decreases slightly as the cost of urea synthesis and excretion increases.

\section{Areas in need of development}

In relating the absorbed nutrient inputs to dietary situations, two important points should be noted. Firstly, nutrients are metabolized by the gut and hence measurement of VFA production or disappearance of nutrients between duodenum and ileum does not equate with absorbed nutrients reaching the liver (Bergman, 1975). Secondly, the proportional contribution of individual nutrients may vary with different levels of intake of one diet, although evidence for this is conflicting (Ulyatt \& MacRae, 1974; Tamminga et al. 1979; McAllan \& Smith, 1983). There is insufficient information on both these points to permit their consideration within the model. However, study of the data in Table 8 shows that if the percentage glucose increased with increased intake, the efficiency could be expected to increase, but if the proportion of protein in the absorbed energy increased with intake, then protein deposition would increase, resulting in a decreased efficiency because of the lower energetic efficiency of protein deposition compared with fat deposition (Kielanowski, 1965, 1966).

In conclusion, the model provides a mathematical representation of energy metabolism in young, growing sheep. This representation justifies the hypothesis that changes in the balance of individual nutrients absorbed could account for some of the variability in $k$ and, in particular, that the rate of NADPH production could limit fat synthesis and hence efficiency, provided that the assumptions inherent in the model are accepted. Validation of the model highlighted the inadequacy of data giving complete profiles of nutrient absorption in relation to both experimental determination of $k_{f}$ and the metabolism of individual nutrients.

The authors are indebted to D. G. Sweeney for assistance with computing matters, and to the Computer Department, Rothamsted Experimental Station and the AFRC Computing Centre, Harpenden, for use of their facilities. One of the authors (J.L.B.) received financial assistance from the Underwood Fund and this is gratefully acknowledged. The Grassland Research Institute is financed through the Agricultural and Food Research Council; the work is in part commissioned by the Ministry of Agriculture, Fisheries and Food. 


\section{REFERENCES}

Agricultural Research Council (1980). The Nutrient Requirements of Farm Livestock No. 2. Ruminants. Farnham Royal: Commonwealth Agricultural Bureaux.

Annison, E. F., Brown, R. E., Leng, R. A., Lindsay, D. B. \& West, C. E. (1967). Biochemical Journal 104, $135-147$. Annison, E. F. \& White, R. R. (1961). Biochemical Journal 80, 162-169.

Armstrong, D. G. (1965). In Physiology of Digestion in the Ruminant, pp. 272-288 [R. W. Dougherty, editor]. Washington, DC: Butterworths.

Armstrong, D. G. \& Blaxter, K. L. (1957). British Journal of Nutrition 11, 247-272.

Armstrong, D. G. \& Blaxter, K. L. (1961). In 2nd Symposium on Energy Metabolism, pp. 187-197 [E. Brouwer and A. J. Van Es, editors]. EAAP Publication no. 10. Wageningen: EAPP.

Armstrong, D. G., Blaxter, K. L., Graham, N. McC. \& Wainman, F. W. (1958). British Journal of Nutrition 12, 177-188.

Baldwin, R. L. \& Black, J. L. (1979). CSIRO Animal Research Laboratories Technical Paper no. 6. Melbourne: CSIRO.

Ballard, F. J., Filsell, O. H. \& Jarrett, I. G. (1972). Biochemical Journal 226, 193-200.

Ballard, F. J., Hanson, R. W. \& Kronfeld, D. S. (1969). Federation Proceedings 28, 218-231.

Bauman, D. E., Mellenberger, R. W. \& Derrig, R. G. (1973). Journal of Dairy Science 56, 1312-1318.

Bergman, E. N. (1975). In Digestion and Metabolism in the Ruminant, pp. 292-305 [I. W. McDonald and A. C. I. Warner, editors]. Armidale: University of New England Publishing Unit.

Black, J. L. (1974). Proceedings of Australian Society of Animal Production 10, 211-218.

Black, J. L. (1983). In Sheep Production, pp. 21-58 [W. Haresign, editor]. London: Butterworths.

Black, J. L. \& Griffiths, D. A. (1975). British Journal of Nutrition 33, 399-413.

Black J. L. \& Reis, P. J. (1979). In Physiological and Environmental Limitations to Wool Growth, pp. 269-293 [J. L. Black and P. J. Reis, editors]. Armidale: University of New England Publishing Unit.

Blaxter, K. L. (1961). In 2nd Symposium on Energy Metabolism, pp. 211-225 [E. Brouwer and A. J. H. van Es, editors]. EAAP Publication no. 10. Wageningen: EAPP.

Blaxter, K. L. (1962). The Energy Metabolism of Ruminants. London: Hutchinson Scientific \& Technical.

Blaxter, K. L. (1969). In Energy Metabolism of Farm Animals, pp. 21-28 [K. L. Blaxter, J. Kielanowski and G. Thorbeck, editors]. Newcastle upon Tyne: Oriel Press.

Blaxter, K. L. (1976). In Energy Metabolism of Farm Animals, pp. 129-132 [M. Vermonel, editor]. EAAP Publication no. 19. Vichy: EAPP.

Blaxter, K. L. \& Wainman, F. W. (1961). Journal of Agricultural Science, Cambridge 57, 419-425.

Breirem, K. (1944). Kungliga Lantbruksakademiens Tidskrift 83, 345-405.

Brouwer, E. (1965). In Energy Metabolism, pp. 441-443 [K. L. Blaxter, editor]. London: Academic Press.

Duncan, W. R. H. \& Garton, G. A. (1978). British Journal of Nutrition 40, 29-33.

Egan, A. R. (1977). Australian Journal of Agricultural Research 28, 907-915.

Elliott, J. M. (1980). In Digestive Physiology and Metabolism in Ruminants, pp. 485-504 [Y. Ruckebusch and P. Thivend, editors]. Lancaster: MTP Press.

Elliott, R., Ferreiro, H. M., Priego, A. \& Preston, T. R. (1978). Tropical Animal Production 3, 30-35.

Garton, G. A., Hovell, F. D. DeB. \& Duncan, W. R. H. (1972). British Journal of Nutrition 28, $409-416$.

Graham, N. McC. (1982). In Energy Metabolism of Farm Animals, pp. 108-111 [A. Epern and F. Sundstøl, editors]. EAAP Publication no. 29. Lillehammer: EAPP.

Graham, N. McC., Black, J. L., Faichney, G. J. \& Amold, G. W. (1976). Agricultural Systems 1, 113-138.

Hovell, F. D. DeB., Greenhalgh, J. F. D. \& Wainman, F. W. (1976). British Journal of Nutrition 35, $343-363$.

Ingle, D. L., Bauman, D. E. \& Garrigus, U. S. (1972). Journal of Nutrition 102, 609-616.

Judson, G. J., Filsell, O. H. \& Jarrett, I. G. (1976). Australian Journal of Biological Science 29, $215-222$.

Judson, G. J. \& Leng, R. A. (1973). British Journal of Nutrition 29, 159-174.

Kielanowski, J. (1965). In Energy Metabolism, pp. 13-20 [K. L. Blaxter, editor]. London: Academic Press.

Kielanowski, J. (1966). Animal Production 8, 121-128.

Leng, R. A. \& Annison, E. F. (1963). Biochemical Journal 86, 319-327.

Lindsay, D. B. (1976). In Protein Metabolism and Nutrition, pp. 183-196 [D. J. A. Cole, K. N. Boorman, P. J. Buttery, D. Lewis, R. J. Neale and H. Swan, editors]. London: Butterworths.

Lobley, G. E. \& Reeds, P. J. (1980). In Proceedings of the 3rd EAAP Symposium on Protein Metabolism and Nutrition, pp. 80-86 [H. J. Oslage and K. Rohr, editors]. EAAP Publication no. 27. Braunschweig: EAAP.

Lonsdale, C. R. \& Tayler, J. C. (1971). Animal Production 13, 384.

Lopez, J. \& Preston, T. R. (1978). Tropical Animal Production 2, $143-147$.

McAllan, A. B. \& Smith, R. H. (1983). British Journal of Nutrition 49, 119-129.

MacRae, J. C. \& Lobley, G. E. (1982). Livestock Production Science 9, 447-456.

McVeigh, J. M. \& Tarrant, P. V. (1982). Journal of Nutrition 112, $1306-1314$.

Mahler, H. R. \& Cordes, E. H. (1971). Biological Chemistry, 2nd ed. New York: Harper and Row.

Martin, A. K. \& Blaxter, K. L. (1965). In Energy Metabolism, pp. 83-91 [K. L. Blaxter, editor]. London: Academic Press.

Ministry of Agriculture, Fisheries and Food (1975). Energy Allowances and Feeding Systems for Ruminants, Technical Bulletin no. 33. London: H.M. Stationery Office. 
Mitchell, E. E. L. \& Gauthier, J. (1981). Advanced Computer Simulation Language (ACSL). Mitchell and Gauthier, Assoc., Inc., P.O. Box 685, Concord, Mass. 01742.

Murray, D. M. \& Slezacek, O. (1976). Journal of Agricultural Science, Cambridge 87, 171-179.

Oldham, J. D. (1981). In Recent Advances in Animal Nutrition - 1980, pp. 33-65 [W. Haresign and D. Lewis, editors]. London: Butterworths.

Orskov, E. R. \& Allen, D. M. (1966). British Journal of Nutrition 20, 295-305.

Pethick, D. W., Lindsay, D. B., Barker, P. J. \& Northrop, A. J. (1981). British Journal of Nutrition 46, 97-109.

Pion, R. (1976). In Protein Metabolism and Nutrition, pp. 259-278 [D. J. A. Cole, K. N. Boorman, P. J. Buttery, D. Lewis, R. J. Neale and H. Swan, editors]. London: Butterworths.

Preston, T. R., Carcano, C., Alvarez, F. J. \& Gutierrez, D. G. (1976). Tropical Animal Production 1, $150-161$.

Reeds, P. J., Wahle, K. W. J. \& Haggarty, P. (1982). Proceedings of the Nutrition Society 41, 155-159.

Reich, J. G. \& Sel'kov, E. E. (1981). Energy Metabolism of the Cell-a Theoretical Treatise. New York: Academic Press.

Rook, J. A. F., Balch, C. C., Campling, R. C. \& Fisher, L. J. (1963). British Journal of Nutrition 17, $399-406$.

Schulz, A. R. (1978). British Journal of Nutrition 39, 235-254.

Searle, T. W. \& Griffiths, D. A. (1976). Journal of Agricultural Science, Cambridge 86, 483-493.

Speckhart, F. H. \& Green, W. L. (1976). A Guide to Using CSMP-the Continuous System Modelling Program. Englewood Cliffs, New Jersey: Prentice-Hall.

Sugden, M. C., Sharpes, S. C. \& Randle, P. J. (1976). Biochemical Journal 160, 817-819.

Sutton, J. D. \& Morant, S. V. (1979). In Ruminant Digestion and Feed Evaluation, pp. 7.1-7.10 [D. F. Osbourn, D. E. Beever and D. J. Thomson, editors]. London: Agricultural Research Council.

Tamminga, S., van der Kvelen, C. J. \& van Vuren, A. M. (1979). Livestock Production Science 6, $255-263$.

Thomson, D. J., Fenlon, J. S. \& Cammell, S. B. (1979). British Joumal of Nutrition 41, 223-229.

Thornley, J. H. M. (1976). Mathematical Models in Plant Physiology. London: Academic Press.

Tyrrell, H. F., Reynolds, P. J. \& Moe, P. W. (1979). Journal of Animal Science 48, 598-606.

Ulyatt, M. J. (1970). Proceedings of the New Zealand Grassland Association 32, $61-68$.

Ulyatt, M. J. \& MacRae, J. C. (1974). Journal of Agricultural Science, Cambridge 82, 295-307.

Vernon, R. G. (1981). In Lipid Metabolism in Ruminant Animals, pp. 279--362 [W. W. Christie, editor]. Oxford: Pergamon Press.

Walker, D. M. \& Norton, B. W. (1971). Journal of Agricultural Science, Cambridge 77, 363-369.

Webster, A. J. F., Osuji, P. O., White, F. \& Ingram, J. R. (1975). British Journal of Nutrition 34, $125-139$.

Yang, Y. T. \& Baldwin, R. L. (1973). Journal of Dairy Science 56, 366-74.

Yang, Y. T., White, L. S. \& Muir, L. A. (1982). Journal of Animal Science 55, 313-320. 